\title{
Kinematic Structure and Dynamics of the Denmark Strait Overflow from Ship-Based Observations
}

\author{
Peigen Lin, ${ }^{\mathrm{a}}$ Robert S. Pickart, ${ }^{\mathrm{a}}$ Kerstin Jochumsen, ${ }^{\mathrm{b}}$ G. W. K. Moore, ${ }^{\mathrm{c}}$ HéðInn Valdimarsson, ${ }^{\mathrm{d}}$ \\ Tim Fristedt, ${ }^{\mathrm{e}}$ AND LAWRENCE J. PRATT ${ }^{\mathrm{a}}$ \\ ${ }^{\mathrm{a}}$ Woods Hole Oceanographic Institution, Woods Hole, Massachusetts; ${ }^{\mathrm{b}}$ Federal Maritime and Hydrographic Agency (BSH), \\ Hamburg, Germany; ${ }^{\mathrm{c}}$ Department of Physics, University of Toronto, Toronto, Ontario, Canada; ${ }^{\mathrm{d}}$ Marine and Freshwater \\ Research Institute, Reykjavik, Iceland; ' Department of Marine Technology, Multiconsult Norway AS, Troms $\phi$, Norway
}

(Manuscript received 6 May 2020, in final form 26 August 2020)

\begin{abstract}
The dense outflow through Denmark Strait is the largest contributor to the lower limb of the Atlantic meridional overturning circulation, yet a description of the full velocity field across the strait remains incomplete. Here we analyze a set of 22 shipboard hydrographic-velocity sections occupied along the Látrabjarg transect at the Denmark Strait sill, obtained over the time period 1993-2018. The sections provide the first complete view of the kinematic components at the sill: the shelfbreak East Greenland Current (EGC), the combined flow of the separated EGC, and the North Icelandic Jet (NIJ), and the northward-flowing North Icelandic Irminger Current (NIIC). The total mean transport of overflow water is 3.54 $\pm 0.29 \mathrm{~Sv}\left(1 \mathrm{~Sv} \equiv 10^{6} \mathrm{~m}^{3} \mathrm{~s}^{-1}\right)$, comparable to previous estimates. The dense overflow is partitioned in terms of water mass constituents and flow components. The mean transports of the two types of overflow water-Atlantic-origin Overflow Water and Arctic-origin Overflow Water-are comparable in Denmark Strait, while the merged NIJ-separated EGC transports 55\% more water than the shelfbreak EGC. A significant degree of water mass exchange takes place between the branches as they converge in Denmark Strait. There are two dominant time-varying configurations of the flow that are characterized as a cyclonic state and a noncyclonic state. These appear to be wind-driven. A potential vorticity analysis indicates that the flow through Denmark Strait is subject to symmetric instability. This occurs at the top of the overflow layer, implying that the mixing/entrainment process that modifies the overflow water begins at the sill.
\end{abstract}

KEYWORDS: Currents; Instability; Ocean circulation; Ocean dynamics; Potential vorticity; Transport

\section{Introduction}

The dense water formed in the Nordic Seas is the main source of lower North Atlantic Deep Water that plays an essential role in the Atlantic meridional overturning circulation (AMOC) (Dickson and Brown 1994). Studies have now demonstrated that the dominant contribution to the AMOC is associated with the warm-to-cold transformation that occurs in the Nordic Seas as opposed to that which takes place in the Labrador Sea (Pickart and Spall 2007; Holte and Straneo 2017; Lozier et al. 2019). Denmark Strait is one of the key passages through which the dense water from the Nordic domain enters the North Atlantic Ocean. The so-called Denmark Strait Overflow Water (DSOW) accounts for roughly half of the total dense water flowing over the Greenland-Scotland Ridge. The mean transport of DSOW at the sill, which is typically defined as water denser than $27.8 \mathrm{~kg} \mathrm{~m}^{-3}$, is estimated to be $3.2-3.5 \mathrm{~Sv}$ (Harden et al. 2016; Jochumsen et al. 2017). The other main passage of overflow water is the Iceland-Scotland ridge, accounting for $\sim 3 \mathrm{~Sv}$, including approximately $1 \mathrm{~Sv}$ via Iceland-Faroe Ridge, and approximately $2 \mathrm{~Sv}$ via the Faroe Bank Channel (Østerhus et al. 2008).

There are three different pathways that advect the dense water into Denmark Strait from the north, supplying the overflow water (Fig. 1): the shelfbreak East Greenland Current (EGC); the separated EGC; and the North Icelandic Jet (NIJ). The EGC emanates from Fram Strait and is a

Corresponding author: Peigen Lin, plinwhoi@gmail.com surface-intensified flow transporting Atlantic-origin Overflow Water at depth. At these latitudes it is composed of a shelfbreak branch and an offshore slope branch (Håvik et al. 2017a). Together they advect a combination of warm, salty water that has been modified along the rim current system of the Nordic Seas (Mauritzen 1996) and also in the high Arctic (Rudels et al. 2005). The shelfbreak EGC transport decreases as it progresses southward, while the slope branch appears to be diverted eastward into the interior north of the Iceland Sea (Håvik et al. 2017a). When the shelfbreak EGC reaches the northern end of the Blosseville Basin it bifurcates to form the separated EGC (Fig. 1). Våge et al. (2013) attribute the bifurcation to local wind stress curl and topography, as well as baroclinic instability of the shelfbreak current.

The NIJ is a middepth-intensified current on the north Iceland slope that transports Arctic-origin Overflow Water equatorward. This is water that has been modified in the interior basins of the western Nordic Seas, and is colder, fresher, and denser than the Atlantic-origin Overflow Water. It was hypothesized by Våge et al. (2011) that the NIJ is part of a local overturning loop in the Iceland Sea whereby the subtropicalorigin water transported northward by the North Icelandic Irminger Current (NIIC, Fig. 1) is fluxed into the interior of the basin and converted to overflow water by wintertime air-sea heat loss. The dense water then progresses back to the Iceland slope where it sinks and feeds the NIJ. However, it has since been demonstrated that the bulk of the Arctic-origin water must originate from farther north where the wintertime mixed layers are denser (Våge et al. 2015). Recent analysis 


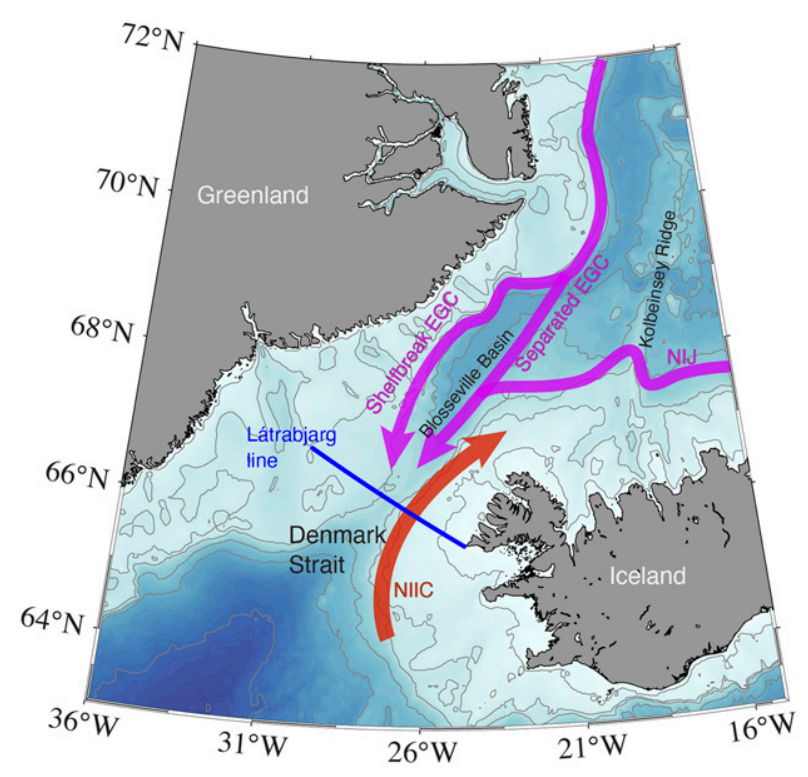

FIG. 1. Schematic circulation in the vicinity of Denmark Strait, including the two branches of the East Greenland Current (EGC) - the shelfbreak EGC and separated EGC-as well as the North Icelandic Jet (NIJ) and the North Icelandic Irminger Current (NIIC). The blue line across Denmark Strait is the Látrabjarg transect from Mastropole et al. (2017). The bathymetry is from ETOPO2v2. Bathymetry contours are in meters.

of the historical data suggests that the water stems from the Greenland Sea (Huang et al. 2020). Based on a large collection of shipboard transects occupied over 15 years, Semper et al. (2019) documented that the NIJ steadily increases in transport, particularly in the downstream of Kolbeinsey Ridge (Fig. 1), as it flows toward Denmark Strait, accounting for a sizable fraction of the dense water that overflows the sill.

Using data from a yearlong mooring array across the Blosseville Basin (roughly $200 \mathrm{~km}$ north of the sill), Harden et al. (2016) calculated mean transports for the three individual pathways: $1.50 \pm 0.16 \mathrm{~Sv}$ for the shelfbreak EGC, $1.04 \pm 0.15 \mathrm{~Sv}$ for the separated EGC, and $1.00 \pm 0.17 \mathrm{~Sv}$ for the NIJ. There was very little seasonal variation, in line with the weak seasonality observed at the sill (Jochumsen et al. 2012). However, Harden et al. (2016) revealed that the transports of the three branches vary on intraseasonal time scales, and that they tend to compensate each other such that the total overflow transport remains fairly steady. They argued that wind stress curl forcing causes the compensation between the NIJ and the two EGC branches.

On synoptic time scales, the flow of DSOW is highly energetic (Smith 1976; Bruce 1995; Rudels et al. 1999; Girton and Sanford 2003; Käse et al. 2003; von Appen et al. 2017). Using the mooring data from the aforementioned Blosseville Basin array, Huang et al. (2019) demonstrated that high-frequency variability is driven by mean-to-eddy baroclinic conversion at the shoreward edge of the NIJ. Using a yearlong mooring array in Denmark Strait, Moritz et al. (2019) resolved the passage of eddies, finding more anticyclones in the deepest part of the strait and more cyclones west of this. Satellite altimetry data have revealed enhanced levels of surface eddy kinetic energy in the vicinity of the strait (Høyer and Quadfasel 2001; Håvik et al. 2017b).

A series of recent papers have further characterized the high-frequency variability of the DSOW at the sill. Two dominant features have been identified, referred to as boluses and pulses. The former corresponds to the passage of a large lenses of overflow water and are associated with cyclonic circulation (von Appen et al. 2017). Mastropole et al. (2017) identified boluses in 46 out of 111 transects across the strait occupied since 1990. These features export the very densest DSOW. Pulses correspond to a thinning and acceleration of the DSOW layer, and are associated with anticyclonic circulation (von Appen et al. 2017). The two types of features have been identified in a high-resolution numerical model, with characteristics similar to the observations (Almansi et al. 2017). Both the boluses and pulses result in increased transport of DSOW over a period of several days (von Appen et al. 2017). Almansi et al. (2020) have shown that the surges in transport result in the generation of cyclones downstream of the sill. These are the well-known "DSOW cyclones" that emanate from the strait and propagate southward along the East Greenland continental slope (Bruce 1995; Spall and Price 1998; von Appen et al. 2017).

The numerical study of Spall et al. (2019) determined that boluses and pulses are part of a single dynamical process, associated with baroclinic instability of the hydrographic front in Denmark Strait. This front divides the southwardflowing water emanating from the Nordic Seas and the northward-flowing NIIC. The instability process results in frontal meanders that propagate southwestward through the strait. Meander troughs are associated with boluses, whereby the NIIC shifts toward Iceland and more overflow water is present in the center of the strait. Meander crests are associated with pulses, when the NIIC moves farther into the strait toward Greenland. Spall et al. (2019) demonstrated that this process is dictated by the interplay between the confluent mean flow in the strait that tends to sharpen the front, and the baroclinic instability which works to relax the front. These results show that the dynamics of the DSOW are closely tied to those of the NIIC.

Based on the large number of shipboard occupations of the Látrabjarg transect across Denmark Strait (Fig. 1), we now have a good characterization of the two-dimensional hydrographic structure across the strait. However, we lack an analogous view of the kinematic structure. Over the years, moorings have been deployed in the deepest part of the sill, which is referred to as the trough (see Fig. 4). These time series have provided information on the vertical structure and transport of the overflow water (e.g., Jochumsen et al. 2017; von Appen et al. 2017; Spall et al. 2019). Recently a fivemooring array was deployed on the western flank of the trough. Using empirical orthogonal function analysis on the yearlong velocity time series, Jochumsen et al. (2017) found that the first mode reflects a barotropic flow that pulses in time, the second mode represents lateral shifts of the flow, and the third mode corresponds to the mesoscale eddy features noted above, 


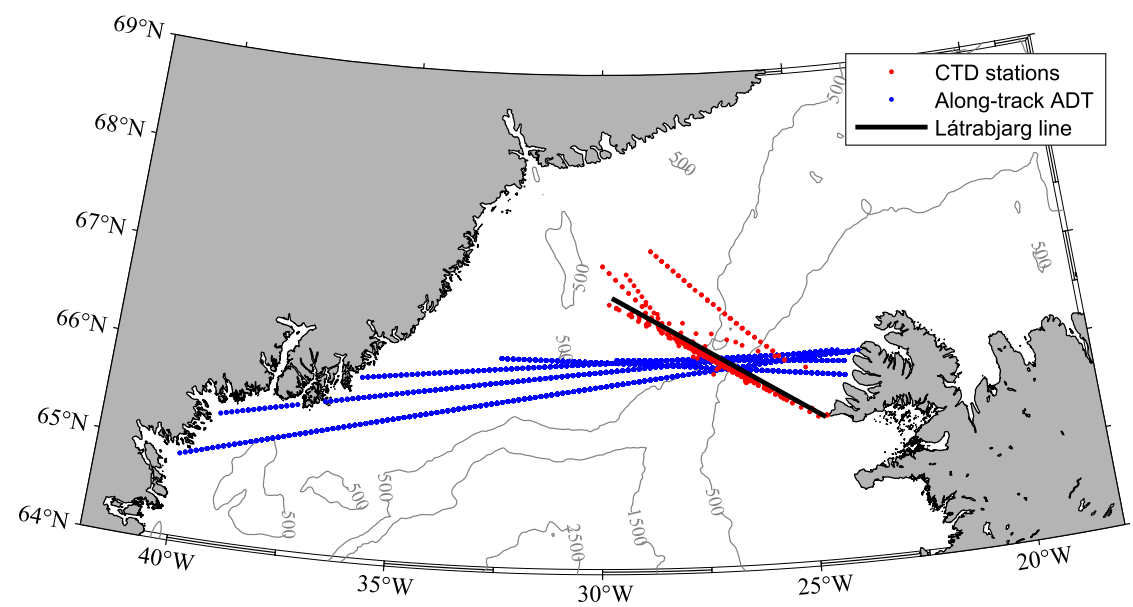

FIG. 2. Locations of the hydrographic and satellite measurements used in the study. The red dots are the CTD stations. There are a total of 122 CTD sections (many of them overlap, hence the dense clustering of red dots). The Látrabjarg transect from Mastropole et al. (2017) is the black line. The blue dots are the absolute dynamic topography (ADT) altimeter measurements.

investigated by Moritz et al. (2019). While these measurements have enhanced our understanding of the flow components in Denmark Strait, they are limited in cross-strait coverage and only have near-bottom temperature and salinity information.

In this study we analyze the updated collection of shipboard occupations of the Látrabjarg line (Fig. 1). The number of occupations is now 122, and, importantly, 22 of them contain direct velocity measurements. This provides the first-ever robust view of the two-dimensional velocity structure across the strait. It enables us to determine the fate of the three abovementioned pathways of overflow water into Denmark Strait, including the water masses they advect and their relationship to the NIIC. We are also able to investigate dynamical aspects of the overflow. The paper is organized as follows. We begin with a presentation of the data. This is followed by a description of the mean hydrographic and velocity structure and the partitioning of the overflow transport by water masses and currents. We then characterize the dominant mode of variability and its relationship to local wind forcing. Finally, we address the hydraulic criticality of the overflow, along with the occurrence of symmetric instability and implications for mixing.

\section{Data and methods}

\section{a. Látrabjarg sections}

We use 122 occupations of the Látrabjarg conductivitytemperature-depth (CTD) transect across Denmark Strait taken between 1990 and 2018 (Fig. 2). This is an updated version of the dataset used by Mastropole et al. (2017), who analyzed 111 of the sections (1990-2012; see Table 1 in Mastropole et al. 2017). As noted in Mastropole et al. (2017), the contributing institutions each applied their own calibration procedures and processing steps. The accuracy of the temperature and salinity measurements are generally deemed to be $0.001^{\circ} \mathrm{C}$ and 0.002 , respectively. A detailed description of the process used for constructing the gridded sections is found in Mastropole et al. (2017). Briefly, each occupation is projected onto the standard Látrabjarg line (black line in Fig. 2), and vertical sections of the hydrographic variables are constructed with a grid spacing of $2.5 \mathrm{~km} \times 10 \mathrm{~m}$. We followed the same procedure for the 11 additional occupations considered here, which are listed in Table 1. We also use direct velocity information obtained on 22 of the sections (Table 1; Fig. 3). This consisted of vessel-mounted acoustic Doppler current profiler (ADCP) data (15 of the occupations) and lowered ADCP data (7 of the occupations). Our study focuses primarily on the 22 occupations with velocity data, except for section 5 where the full historical hydrographic dataset is used.

Absolute geostrophic velocity sections were constructed using the gridded hydrographic sections in conjunction with gridded sections of the cross-track ADCP velocities, following the same procedure as in Pickart et al. (2016). Errors in the volume transport estimates are associated with the instrument uncertainty, the gridding process, and the inability to measure the flow in the bottom triangles (the area beneath the deepest common level of adjacent stations). Because of the generally small station spacing of the sections, the latter effect is taken to be negligible. The instrument uncertainties of both the vesselmounted ADCP and lowered ADCP are taken as $0.02 \mathrm{~m} \mathrm{~s}^{-1}$ (Pickart et al. 2016, 2017). The gridding error was obtained by calculating the differences between the vertically averaged velocity measurement at each station versus the same quantity determined using the gridded values closest to the station (Nikolopoulos et al. 2009), and was found to be on average $0.008 \mathrm{~m} \mathrm{~s}^{-1}$ (with little variation from section to section). The final error is taken to be the root of the sum of the squares of the instrument and gridding errors, $0.022 \mathrm{~m} \mathrm{~s}^{-1}$, and is applied over the area of the section where the transport is being calculated. Since this does not assume that the errors 
TABLE 1. Occupations of the 22 Látrabjarg transects with velocity measurements used in the study. VMADCP: vessel-mounted ADCP; LADCP: lowered ADCP. The 11 occupations marked with an asterisk (*) denote the sections added to the Mastropole et al. (2017) dataset.

\begin{tabular}{|c|c|c|c|c|c|c|}
\hline Cruise & Ship & Year & Date & $\mathrm{ADCP}$ & Bin size $(m)$ & Vertical range $(\mathrm{m})$ \\
\hline WOCE-93* & R/V Aranda & 1993 & 30 Aug & $150 \mathrm{kHz}$ VMADCP & 8 & $28-372$ \\
\hline MSM05-4 & R/V Maria S. Merian & 2007 & 12-13 Jul & 75 kHz VMADCP & 16 & $22-582$ \\
\hline KN194 & R/V Knorr & 2008 & 13-14 Oct & $75 \mathrm{kHz}$ VMADCP & 16 & $31-517$ \\
\hline BS010 & R/V Bjarni Saemundsson & 2009 & 11-12 Aug & 300 kHz LADCP & 5,8 & Full \\
\hline M82-1 & $\mathrm{R} / \mathrm{V}$ Meteor & 2010 & $7 \mathrm{Jul}$ & $38 \mathrm{kHz}$ VMADCP & 32 & $38-518$ \\
\hline BS001 & R/V Bjarni Saemundsson & 2011 & $10 \mathrm{Feb}$ & 300 kHz LADCP & 4,5 & Full \\
\hline M85-2 & R/V Meteor & 2011 & 19-21 Aug & $38 \mathrm{kHz}$ VMADCP & 16 & $18-578$ \\
\hline KN203 & R/V Knorr & 2011 & 22-24 Aug & $75 \mathrm{kHz}$ VMADCP & 8 & $21-549$ \\
\hline BS002 & R/V Bjarni Saemundsson & 2012 & 8-9 Feb & $300 \mathrm{kHz}$ LADCP & $2,4,5$ & Full \\
\hline MSM21-1b & R/V Maria S. Merian & 2012 & 10-11 Jun & $38 \mathrm{kHz}$ VMADCP & 32 & $14-582$ \\
\hline JR267 & R/V James Clark Ross & 2012 & 28-29 Jul & $300 \mathrm{kHz}$ LADCP & 5 & Full \\
\hline P437 & R/V Poseidon & 2012 & 10-12 Aug & $75 \mathrm{kHz}$ VMADCP & 8 & $16-624$ \\
\hline BS013* & R/V Bjarni Saemundsson & 2013 & 6-7 Feb & $300 \mathrm{kHz}$ LADCP & 2,5 & Full \\
\hline P471-2* & R/V Poseidon & 2014 & $6-8 \mathrm{Feb}$ & $75 \mathrm{kHz}$ VMADCP & 16 & $20-596$ \\
\hline P486* & R/V Poseidon & 2015 & 14-25 Jun & $75 \mathrm{kHz}$ VMADCP & 16 & $20-548$ \\
\hline BS015* & R/V Bjarni Saemundsson & 2015 & 24 Aug & 300 kHz LADCP & 4,8 & Full \\
\hline P503* & R/V Poseidon & 2016 & 4-6 Aug & $75 \mathrm{kHz}$ VMADCP & 16 & $35-535$ \\
\hline BS017* & R/V Bjarni Saemundsson & 2017 & 5-6 Aug & 300 kHz LADCP & 2,4 & Full \\
\hline 64PE426* & R/V Pelagia & 2017 & $16-18 \mathrm{Sep}$ & $75 \mathrm{kHz}$ VMADCP & 16 & $35-405$ \\
\hline ALL0118* & NRV Alliance & 2018 & 20-21 Mar & $75 \mathrm{kHz}$ VMADCP & 8 & $21-509$ \\
\hline MSM76* & R/V Maria S. Merian & 2018 & 14-15 Aug & $75 \mathrm{kHz}$ VMADCP & 8 & $45-535$ \\
\hline AR306* & $\mathrm{R} / \mathrm{V}$ Armstrong & 2018 & $1 \mathrm{Oct}$ & $75 \mathrm{kHz}$ VMADCP & 8 & $18-402$ \\
\hline
\end{tabular}

are uncorrelated, it represents a conservative estimate. The gridded absolute geostrophic velocities are used for all calculations presented in this study.

\section{b. Reanalysis wind data}

Wind fields from ERA5 were obtained from the European Centre for Medium-Range Weather Forecasts (ECMWF, https://www.ecmwf.int/). This is the fifth generation reanalysis, which uses ECMWF's Integrated Forecast System (IFS). Previous studies have shown good agreement between IFS products and observations (Harden et al. 2016). The spatial resolution of ERA5 is $0.25^{\circ}$. Here we used the 3-hourly product from 1990 to 2018 .

\section{c. Satellite absolute dynamic topography}

The along-track absolute dynamic topography (ADT) data used in the study were provided by the Copernicus Marine and Environment Monitoring Service (CMEMS, http://www.marine.copernicus.eu). The product is processed by the Data Unification and Altimeter Combination System (DUACS) which applies to multimission altimeter data. The data are comprised from the TOPEX/POSEDON mission, together with the Jason-1, Jason-2, and Jason-3 missions. Since Denmark Strait is close to the northern turning point of the orbits, the along-track data have spatial and temporal resolutions of roughly $12 \mathrm{~km}$ and 2 days, respectively. The time period of data coverage used here is 1993-2018. The error in the along-track ADT measurement is $0.7-1.3 \mathrm{~cm}$, which translates to an uncertainty of $0.05-0.10 \mathrm{~m} \mathrm{~s}^{-1}$ in the surface geostrophic velocity (http://marine.copernicus.eu/documents/ QUID/CMEMS-SL-QUID-008-032-051.pdf). We make composite averages which use roughly a thousand crossings each, which substantially reduces this error (see section 4).

\section{Basic characteristics}

\section{a. Mean state}

We first present the mean Látrabjarg sections of hydrography and absolute geostrophic velocity using the 22 realizations that include velocity data (Fig. 4). We do not consider the regions on the east and west side of the strait where the number of occupations is less than five. Encouragingly, the mean distributions of potential temperature and salinity from the 22 occupations are consistent with the analogous means presented in Mastropole et al. (2017) using 111 occupations. It indicates

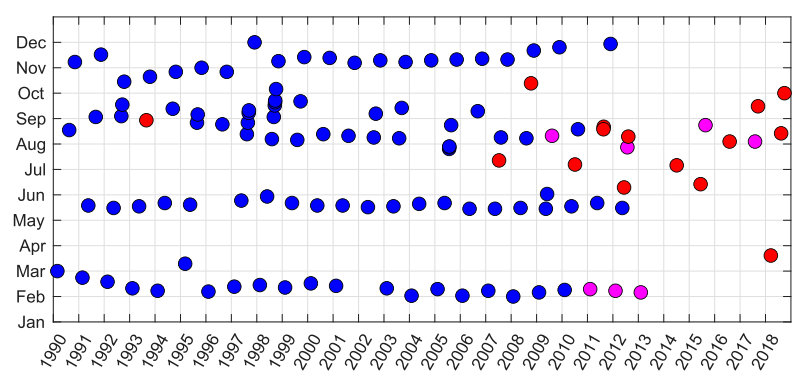

FIG. 3. Temporal distribution of the 122 Látrabjarg hydrographic sections. Those occupations that include velocity measurements are colored red (for vessel-mounted ADCP data) and magenta (for lowered ADCP). The blue circles correspond to hydrographic measurements only. 

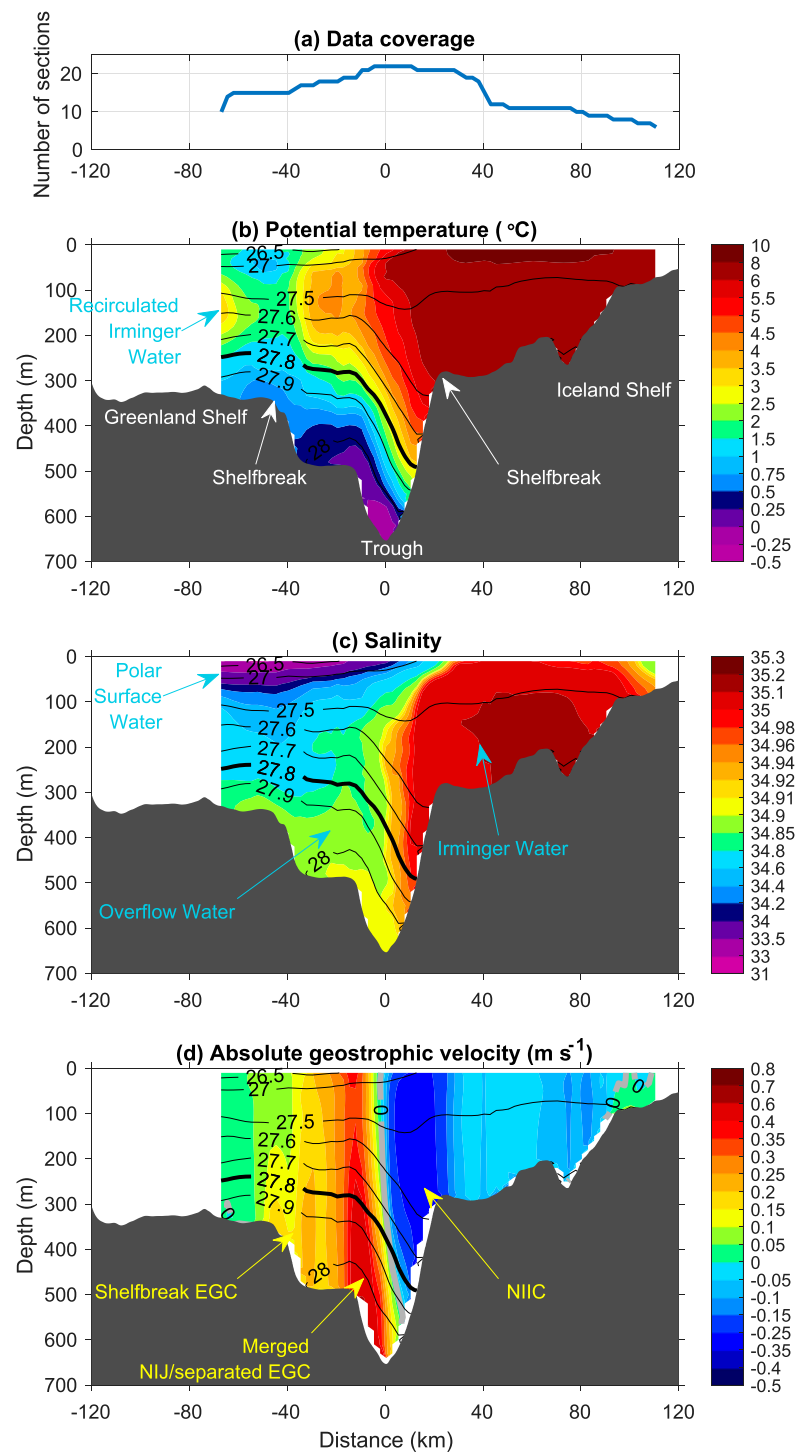

FIG. 4. Mean vertical sections of the 22 occupations of the Látrabjarg transect: (a) data coverage, along with (b) potential temperature $\left({ }^{\circ} \mathrm{C}\right),(\mathrm{c})$ salinity, and (d) absolute geostrophic velocity $\left(\mathrm{m} \mathrm{s}^{-1}\right)$ overlain by potential density $\left(\mathrm{kg} \mathrm{m}^{-3}\right)$ contours. Positive (negative) velocities are equatorward (poleward). The highlighted isopycnal of $27.8 \mathrm{~kg} \mathrm{~m}^{-3}$ is the upper boundary of the overflow water. The Iceland shelf is on the east side of the trough (positive distance), and the Greenland shelf is on the west side (negative distance). Water masses are identified using blue labels.

that our mean view using a smaller number of sections is representative. The warm and salty water on the Iceland shelf is the Irminger Water originating from the south (the nearsurface freshwater at the eastern end of the section is likely associated with the Iceland Coastal Current, Logemann et al. 2013). To the west, the vertically varying temperature and salinity reflects several water masses. In the upper layer, the cold and freshwater, referred to as Polar Surface Water, emanates from the Arctic Ocean via Fram Strait (de Steur et al. 2009; Håvik et al. 2017a). Beneath this, the warm water at the western edge of the section, centered near $150 \mathrm{~m}$, is Irminger Water that has recirculated north of the strait (Mastropole et al. 2017; Casanova-Masjoan et al. 2020). Near the bottom is the DSOW, denser than $27.8 \mathrm{~kg} \mathrm{~m}^{-3}$ (this isopycnal is highlighted in Fig. 4). As noted above, this is a combination of Atlantic-origin Overflow Water (AtOW) and Arctic-origin Overflow Water (ArOW), which is banked up on the western side of the trough (see also Våge et al. 2011; Harden et al. 2016; Mastropole et al. 2017). The breakdown between these water masses is addressed in the next section.

Figure $4 \mathrm{~d}$ shows the mean section of absolute geostrophic velocity. This is the first such view of the average, full water column velocity structure across Denmark Strait. The strong poleward flow in the vicinity of the Iceland shelf break is the NIIC, which transports Irminger Water into the Iceland Sea. Seaward of the NIIC there are two bands of southward, bottom-intensified flow associated with tilting isopycnals sloping downward from west to east. The stronger band of flow is located on the western side of the deep trough and transports the densest DSOW. The second band is situated near the East Greenland shelf break. As noted above, the NIJ, separated EGC, and shelfbreak EGC all advect water into Denmark Strait (Fig. 1). The yearlong mooring dataset across the Blosseville Basin used by Harden et al. (2016) revealed that, in the mean, the NIJ and separated EGC were partially merged at that location. Our results demonstrate that, in Denmark Strait, these two currents are fully merged and correspond to the stronger band of flow in Fig. 4d which transports the majority of the DSOW. The weaker band of flow to the west is the shelfbreak EGC. These two distinct bands are seen in the most of individual sections. Note, however, that there is only a slight minimum in flow between the shelfbreak EGC and the merged NIJ-separated EGC (Fig. 4d), which indicates that all three branches have combined to some degree in the narrow strait.

\section{b. Partitioning the DSOW transport}

The transport of DSOW (denser than $27.8 \mathrm{~kg} \mathrm{~m}^{-3}$ ) in the vicinity of Denmark Strait has been estimated in many studies. Harden et al. (2016) reported a yearlong mean value of $3.54 \pm 0.16 \mathrm{~Sv}$ from the mooring array across the Blosseville Basin in 2011-12. Jochumsen et al. (2012) estimated the value to be $3.40 \pm 0.60 \mathrm{~Sv}$ using one or two moorings in the center of the strait from 1996 to 2011. This value was later updated by Jochumsen et al. (2017) to be $3.20 \pm 0.50 \mathrm{~Sv}$, accounting for known biases in the near-bottom current measurements and using a new method developed from extended measurements. In each of these studies the error represents the statistical uncertainty based on the length of the time series. From the mean section of Fig. 4d, we obtain a transport of $3.00 \pm 0.29 \mathrm{~Sv}$ (Table 2, where the uncertainty is the instrument error, as explained above). This is lower than the previous estimates because our mean section only extends $\sim 20 \mathrm{~km}$ west of the East Greenland shelf break. Transects that extend across the entire Denmark Strait reveal that DSOW is found far onto the Greenland shelf, and the limited velocity information there implies weak mean flow (Brearley et al. 2012; Jochumsen et al. 2012). The Greenland shelf contribution in the model 
TABLE 2. Partitioning of the DSOW transport (Sv) by water masses and current components. The values in parentheses include the unresolved portion on the Greenland shelf $(0.54 \mathrm{~Sv})$.

\begin{tabular}{llcc}
\hline \multirow{2}{*}{\multicolumn{1}{c}{ Water masses }} & \multicolumn{3}{c}{ Currents } \\
\cline { 2 - 4 } & \multicolumn{1}{c}{ Shelfbreak EGC } & Merged NIJ-separated EGC & Total \\
\hline Arctic-origin water & $0.41 \pm 0.06$ & $1.31 \pm 0.09$ & $1.72 \pm 0.15$ \\
Atlantic-origin water & $0.33 \pm 0.06$ & $0.62 \pm 0.04$ & $0.95 \pm 0.10(1.49 \pm 0.10)$ \\
Other water masses & $0.11 \pm 0.02$ & $0.22 \pm 0.02$ & $0.33 \pm 0.04$ \\
Total & $0.85 \pm 0.14(1.39 \pm 0.14)$ & $2.15 \pm 0.15$ & $3.00 \pm 0.29(3.54 \pm 0.29)$ \\
\hline
\end{tabular}

of Macrander (2004) is roughly $0.40 \mathrm{~Sv}$, which has been accounted for in the estimates of Jochumsen et al. (2012). Results from a mooring on the Greenland shelf $(30 \mathrm{~km}$ west of the trough) implied a similar value of $0.50 \mathrm{~Sv}$ (Jochumsen et al. 2017) [the mooring array used by Harden et al. (2016) encompassed the DSOW on the Greenland shelf]. Linearly extrapolating our mean section of Fig. 4d to the Greenland coast gives a value of $0.54 \mathrm{~Sv}$ for the missing transport, which is in line with the estimates above. Thus, our adjusted total transport of $3.54 \pm 0.29 \mathrm{~Sv}$ is comparable to the previous DSOW transport estimates.

Our hydrographic and velocity data provide the opportunity to partition the overflow transport by water masses. To do this, we applied the same water mass end-member technique of Mastropole et al. (2017) to our 22 occupations. Mastropole et al. (2017) defined four endmembers: AtOW, ArOW, Polar Surface Water (PSW), and Irminger Water (IW). These are shown in the $T-S$ plane in Fig. 5a [see Fig. 6 of Mastropole et al. (2017) for a geographical context]. Mastropole et al. (2017) devised two mixing triangles, one of which used the first three water masses, and the other using the latter three water masses (Fig. 5a), the assumption being that AtOW does not mix with Irminger Water. For each station of a given occupation we computed the corresponding end-member percentages, then gridded these to make vertical sections. The mean sections of percentage for the four water masses are shown in Fig. 5.

The ArOW dominates the deep trough where the merged NIJ-separated EGC is located, accounting for close to $100 \%$ of the overflow water near the bottom (Fig. 5b). By contrast, the AtOW percentage is highest in the vicinity of the Greenland shelf break, with large values in the shelfbreak EGC (Fig. 5c). Note, however, that the percentage of ArOW is comparable to that of the AtOW in this region-this further indicates merging/mixing of the three branches. For the other two end members, the Polar Surface Water and Irminger Water, the mean percentages are quite small in the overflow water (Figs. 5d,e). While there is some section to section variability in ArOW and AtOW percentages for the merged NIJ-separated EGC and shelfbreak EGC, the standard deviations are only between $6 \%$ and $8 \%$.

Using the mean water mass end-member percentage sections (Fig. 5) in conjunction with the mean velocity section (Fig. 4d), we get a transport of $1.72 \pm 0.15 \mathrm{~Sv}$ for ArOW and $0.95 \pm 0.10 \mathrm{~Sv}$ for AtOW (Table 2). If we assume that the unresolved portion of the flow on the Greenland shelf is predominantly AtOW, this boosts the transport of this water mass to $1.49 \pm 0.10 \mathrm{~Sv}$. Hence, we conclude that the mean transports of the two types of overflow water are comparable in Denmark Strait. The remaining transport $(0.33 \pm 0.04 \mathrm{~Sv})$ corresponds to the small contributions from the Polar Surface Water and Irminger Water getting mixed into the top of the overflow layer.

As noted in the introduction, Harden et al. (2016) partitioned the overflow transport into the three flow branches using data from the upstream Blosseville Basin mooring array. Using four shipboard occupations of the same line, Våge et al. (2013) did the same partitioning with generally consistent results. While the two bands of enhanced southward flow in our mean velocity section reflect the shelfbreak EGC and merged NIJ-separated EGC, respectively (Fig. 4d), the degree to which all three branches have merged/mixed in the strait makes it impossible to do precise partitioning here. It is nonetheless instructive to consider the geographical distribution of the overflow transport.

We specify the boundary between the nominal shelfbreak EGC and merged NIJ-separated EGC to be $-25 \mathrm{~km}$ (i.e., the location of the velocity minimum between the two bands, Fig. 4d). It follows that the shelfbreak EGC transports $0.85 \pm 0.14 \mathrm{~Sv}$, while the merged flow accounts for $2.15 \pm$ $0.15 \mathrm{~Sv}$ (Table 2). By comparison, Harden et al. (2016) calculated $1.50 \pm 0.16 \mathrm{~Sv}$ for the shelfbreak EGC and $2.04 \pm 0.16 \mathrm{~Sv}$ for the merged flow. It is safe to assume that the inshore flow on the Greenland shelf at the Látrabjarg line originated from the shelfbreak EGC upstream (recall that Blosseville mooring array captured all of the overflow water on the Greenland side, which was confined to the region of the shelf edge). This increases our shelfbreak EGC transport to $1.39 \pm 0.14 \mathrm{~Sv}$, in line with the Blosseville Basin estimate. Hence, our total transport, as well as the geographical distribution of transport across the strait, is consistent with Harden et al.'s (2016) upstream partitioning. With regard to the overflow water masses, our mean sections (Figs. 4d and 5) indicate that the band of flow at the shelf break transports comparable amounts of AtOW and ArOW, while the band of flow on the western flank of the trough transports roughly twice as much ArOW as AtOW (Table 2). Again, this attests to the significant degree of exchange between the flow branches as they converge in Denmark Strait.

\section{Dominant variability}

We now consider the section to section variability in our 22 occupations, which is a reflection of mesoscale processes. Using a mooring in the center of the Denmark Strait trough, von Appen et al. (2017) showed that the two pronounced 


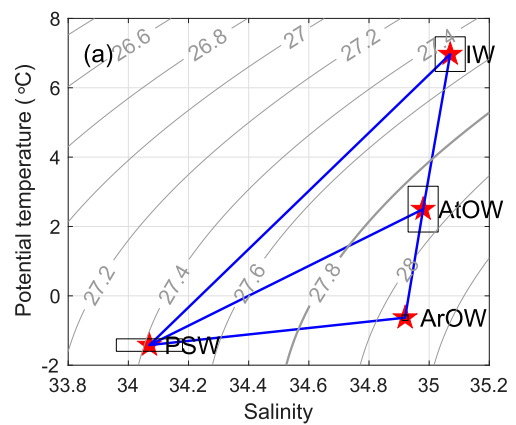

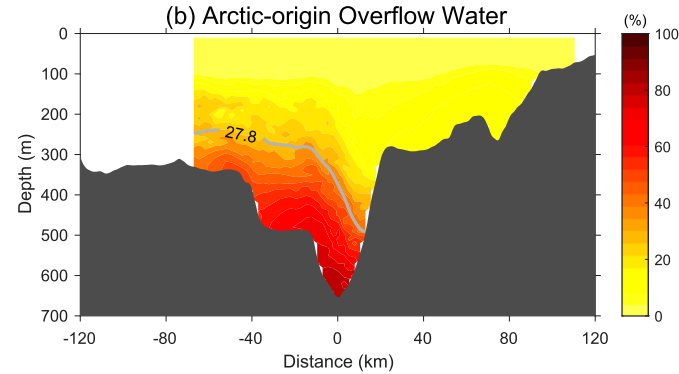

(d) Polar Surface Water

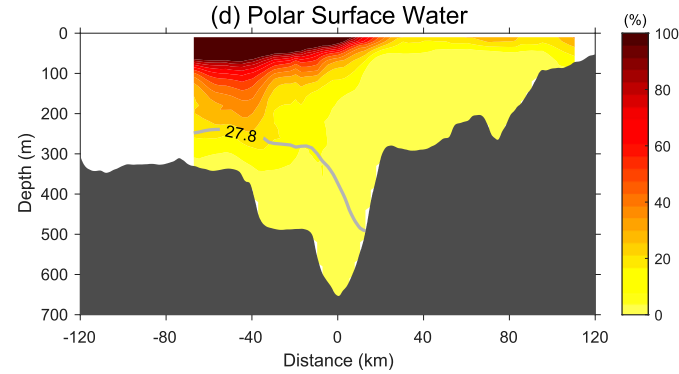

(c) Atlantic-origin Overflow Water

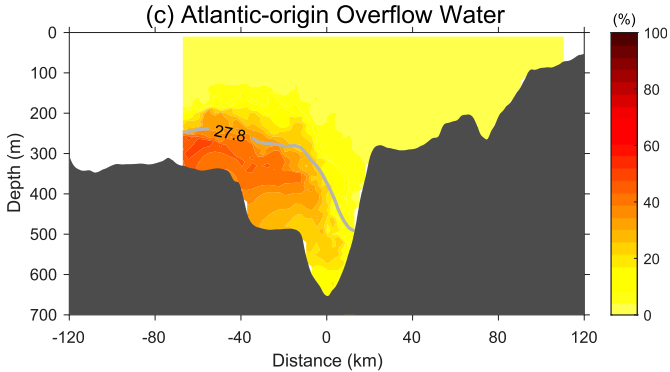

(e) Irminger Water

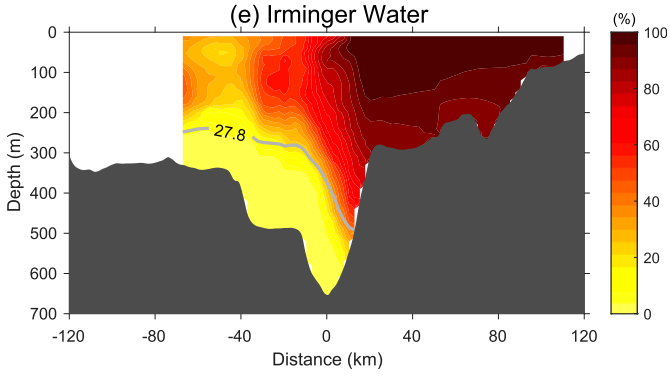

FIG. 5. (a) Water mass end members identified by Mastropole et al. (2017) and used in this study (stars), including the uncertainty (boxes), plotted in the $T-S$ plane. The contours are potential density $\left(\mathrm{kg} \mathrm{m}^{-3}\right)$. Atlantic-origin Overflow Water (AtOW): $2.50^{\circ} \pm 0.66^{\circ} \mathrm{C}, 34.98 \pm 0.05$; Arctic-origin Overflow Water (ArOW): $-0.63^{\circ} \pm 0.66^{\circ} \mathrm{C}$, $34.92 \pm 0.01$; Polar Surface Water (PSW): $-1.42^{\circ} \pm 0.18^{\circ} \mathrm{C}, 34.07 \pm 0.11$; Irminger Water (IW): $6.97^{\circ} \pm 0.18^{\circ} \mathrm{C}$, $35.07 \pm 0.05$. (b)-(e) Mean vertical sections of percentage presence of (b) the ArOW end member, (c) the ArOW end member, (d) the PSW end member, and (e) the IW end member. The highlighted isopycnal of $27.8 \mathrm{~kg} \mathrm{~m}^{-3}$ is the upper boundary of the overflow water.

mesoscale features, boluses, and pulses, are associated with a cyclonic and anticyclonic sense of rotation, respectively. Following the definitions in Mastropole et al. (2017), we identified eight instances of a bolus and nine instances of a pulse in our collection of sections ( 5 sections could not be classified as either type of feature). We found relatively little difference in the across-strait structure of the alongstream velocity field in these two scenarios. However, inspection of the individual sections revealed 15 cases characterized by a strong cyclonic structure centered in the trough. Figure 6 shows the composite mean of these realizations, compared to the composite of the remaining seven sections (where again we have only plotted regions with at least five realizations). In the former case, which is referred to as the cyclonic state, both the northward-flowing NIIC near the Iceland shelf break and the southward-flowing merged NIJ-separated EGC on the western flank of the trough are intensified, while the shelfbreak EGC is weakened. In the latter case, referred to as the noncyclonic state, the entire trough contains equatorward flow, but it is weaker and more bottom-trapped. In addition, the NIIC is weaker but there is enhanced poleward flow over much of the Iceland shelf. (The data coverage is insufficient to say anything about the shelfbreak EGC in this state.) The hydrographic structure is not noticeably different in the two states (not shown). The height of the overflow layer (i.e., the height of the $27.8 \mathrm{~kg} \mathrm{~m}^{-3}$ isopycnal) is also similar in both composites, although the stronger flow in the cyclonic composite results in a larger transport of DSOW. It is clear that these two states are not reflective of boluses and pulses, which, as noted above, correspond to large differences in overflow layer height. This begs the question: what is the nature of this dominant variability? We argue that it is related to wind forcing.

To help demonstrate this, we first characterized the velocity structure in the center of each section by the lateral gradient of the depth-mean velocity across the trough. This is an effective 
(a) Cyclonic
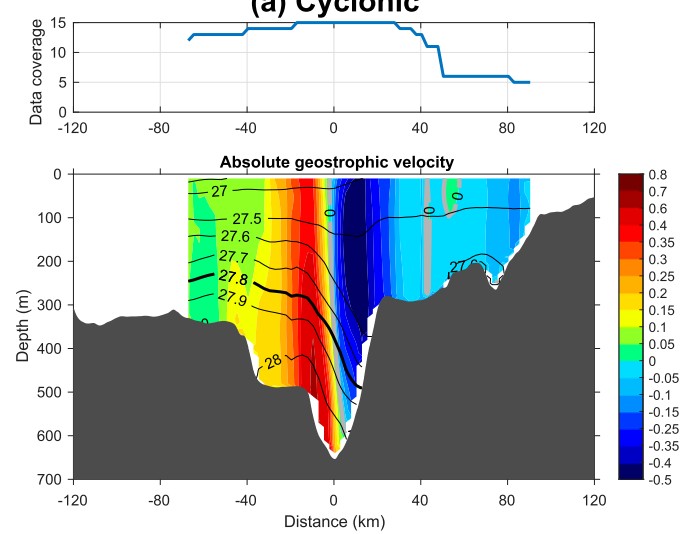

(b) Non-cyclonic
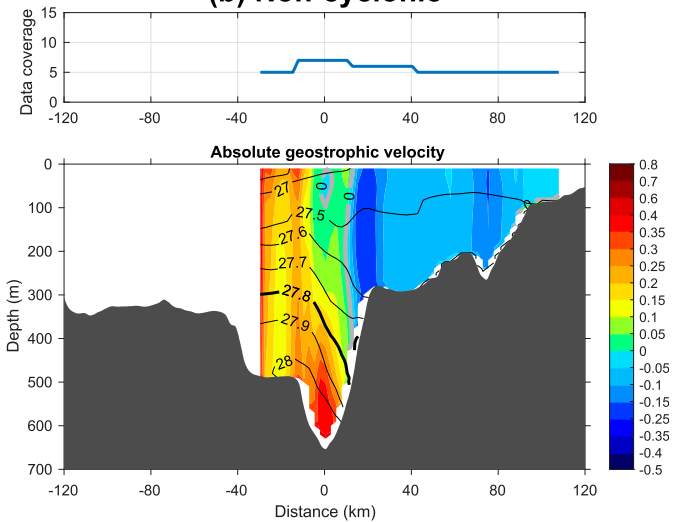

FIG. 6. (bottom) Composites of absolute geostrophic velocity ( $\mathrm{m} \mathrm{s}^{-1}$, colors) overlain by potential density $\left(\mathrm{kg} \mathrm{m}^{-3}\right.$, contours) for the (a) cyclonic and (b) noncyclonic cases. Positive velocities are equatorward. The highlighted isopycnal of $27.8 \mathrm{~kg} \mathrm{~m}^{-3}$ is the upper boundary of the overflow water. (top) The data coverage.

metric that characterizes the degree to which a given section is in the cyclonic state (i.e., the stronger the gradient, the more cyclonic, and vice versa). Using the ERA5 reanalysis wind data, we then created composites of the wind stress curl and wind vectors for the two extremes of the velocity gradient, in particular the five strongest cases and five weakest cases (Fig. 7). The mean wind field during the time of occupation the sections (see Table 1) go into the composites. In the former, the wind in Denmark Strait is strongly out of the northeast and there is pronounced negative wind stress curl over the Blosseville Basin. In the other extreme, the wind is weak and variable, while the wind stress curl is weakly positive over the Blosseville Basin. Våge et al. (2013) showed that negative wind stress curl, together with the closed isobaths of the Blosseville Basin, plays an important role in the bifurcation of the EGC at the northern edge of the basin. This in turn would weaken the shelfbreak EGC. Hence, the wind stress curl pattern in Fig. 7a is conducive for enhancement of the merged NIJ-separated EGC in the trough and decreased flow of the shelfbreak EGC, as seen in the composite of Fig. 6a. In the other extreme the wind stress curl would weaken the merged flow, consistent with the composite of Fig. 6 b.

The wind stress curl forcing, however, does not explain the variation in the NIIC between the two states. To address the potential role of the along-strait wind, we employed the alongtrack ADT data (Fig. 2 shows the satellite tracks in the region). Using the 25 years of ADT data, we computed the cross-track component of surface geostrophic velocity for each of the satellite crossings and projected these to the Látrabjarg line [see Spall et al. (2019) for details on the methodology]. We note that both the NIIC and merged NIJ-separated EGC have a strong surface signature (while the shelfbreak EGC does not, Fig. 4). Next, we created composites of the surface
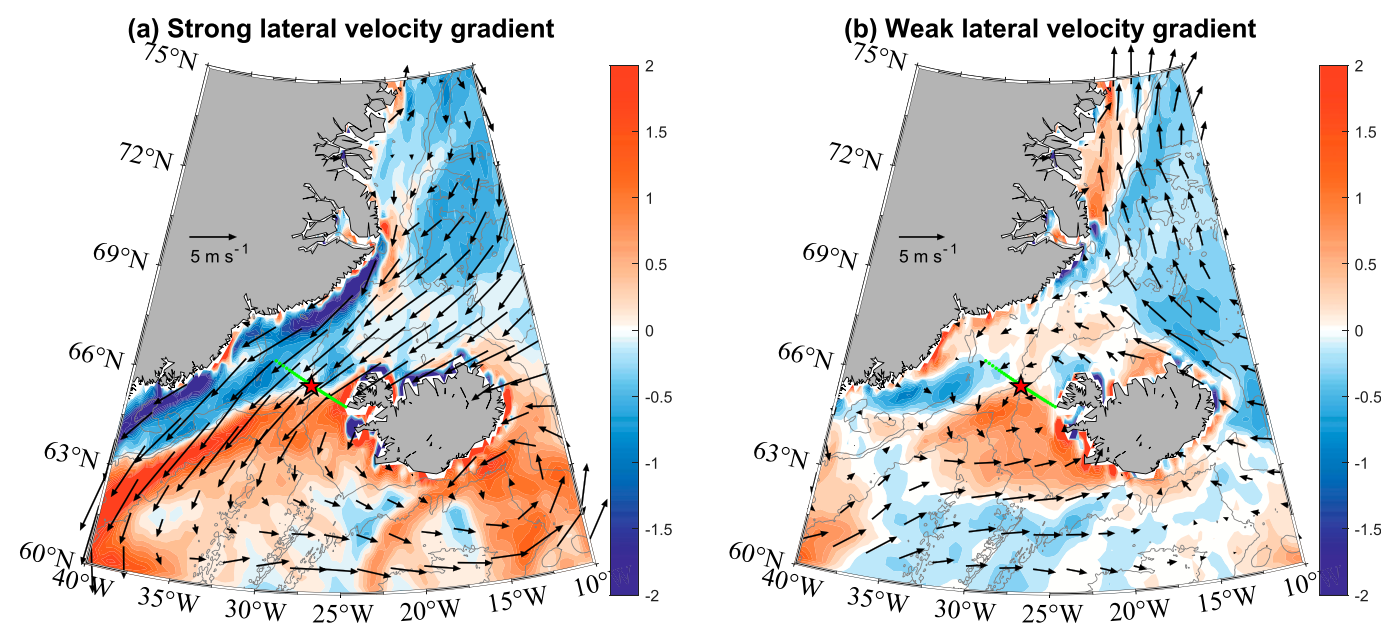

FIG. 7. Composites of wind stress curl $\left(\times 10^{-6} \mathrm{~N} \mathrm{~m}^{-3}\right.$, colors) and wind vectors (see the key) for the five extreme cases of (a) strong and (b) weak lateral gradients of depth-mean velocity across the Denmark Strait trough. The green line denotes the Látrabjarg transect. The trough is marked by the red star. 


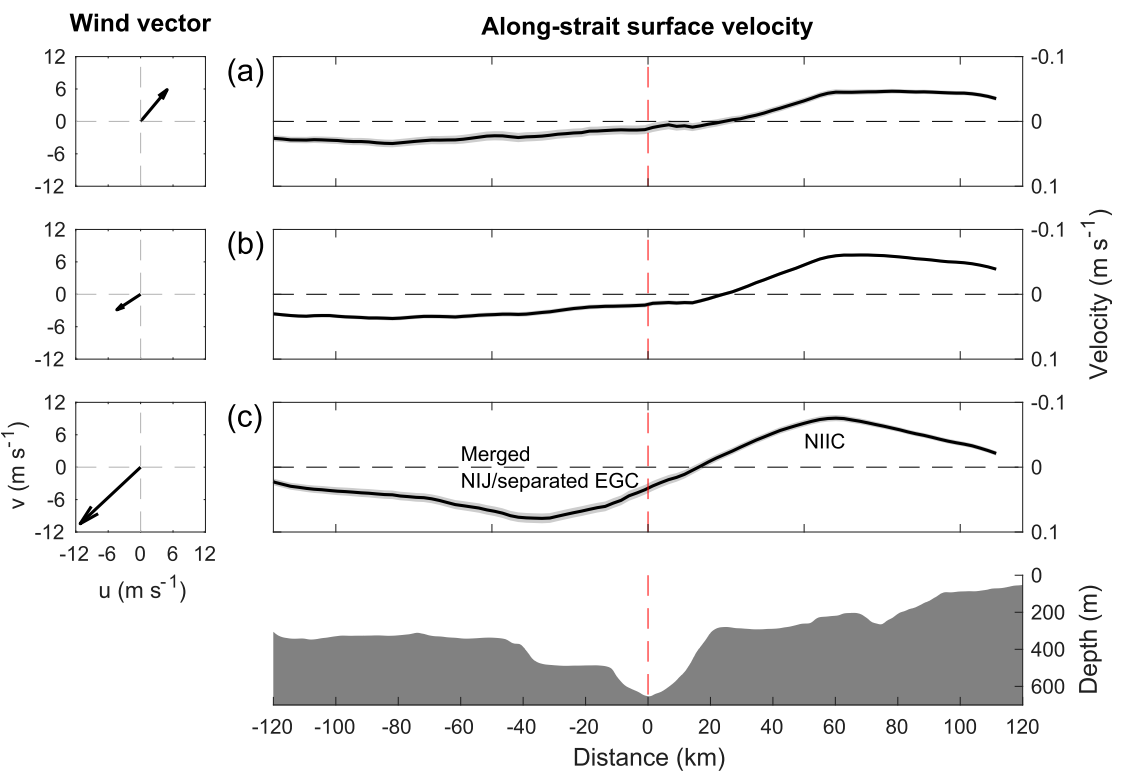

FIG. 8. (right) Composites of along-strait surface geostrophic velocity $\left(\mathrm{m} \mathrm{s}^{-1}\right)$ corresponding to (left) different wind conditions in Denmark Strait. The shading represents the standard error. (a) Average of all instances where the southwesterly wind is greater than the mean plus one standard deviation. (b) Instances where the wind is close to the mean. (c) Instances where the northeasterly wind in the strait is greater than the mean plus one standard deviation. (bottom) The bathymetry.

velocity corresponding to the associated wind conditions in the strait (averaged in a $1^{\circ} \times 1^{\circ}$ box around the trough). In particular, we composited all of the satellite crossings for strong northeasterly wind (greater than the mean plus one standard deviation), strong southwesterly wind (same criterion), and for all remaining cases. The results are shown in Fig. 8. Each of these composites contains on the order of a thousand crossings, and the small standard errors indicate the robustness of the results. The composites demonstrate that when the winds are strongly out of the northeast the NIIC is both stronger and located more seaward, plus the merged NIJ-separated EGC is enhanced as well. This is consistent with the fact that the cyclonic state (Fig. 6a) corresponds to strong northeasterly winds (Fig. 7a).

We note that in Fig. 8c that the signatures of the NIIC and merged NIJ-separated EGC are much broader than in the cyclonic velocity composite, plus the NIIC is located on the Iceland shelf and the merged flow is located near the Greenland shelf break, versus being situated close to the trough. This is likely due in part to the resolution of the altimeter $(12 \mathrm{~km})$, which is not well suited for resolving either flow, plus the compositing process. However, it is also partly due to the fact that not all instances with strong northeasterly wind correspond to a strong NIIC displaced to the west-although this is clearly the case in the mean (Fig. 8c). To assess this, we composited the surface geostrophic velocity for all of the instances when the NIIC was at the edge of the Iceland shelf, regardless of wind conditions. This revealed a significantly narrower, stronger NIIC along with an enhanced southward-flowing merged NIJ-separated
EGC. Importantly, the mean wind for these instances was strongly out of the northeast. This, together with Fig. 8c, indicates that the cyclonic state in Denmark Strait is clearly associated with enhanced northeasterly winds through the strait.

It remains to be determined what the physical mechanism is behind this change in the NIIC. Upwelling-favorable northeasterly winds should drive southward flow on the Iceland shelf due to Ekman setup, i.e., the opposite of an enhanced NIIC, but the altimeter data are too inaccurate near the coast to confirm this. The strong cyclonic flow offshore, in the vicinity of the trough, is associated with a depression of the sea surface height. Such a signature would arise if there was an increase in wind speed near the center of the strait, due to divergence of the offshore Ekman transport. Unfortunately, the spatial resolution of ERA5 $(\sim 30 \mathrm{~km})$ is insufficient to resolve such a change. It should be noted that a two-dimensional view may not be appropriate here because the presence of warm, relatively light water along the south coast of Iceland and cold, dense water along the north slope, will result in an anticyclonic propagation of a high sea surface height signal around the west coast of Iceland (Spall et al. 2017). This would act to maintain a high sea surface height over the Iceland shelf to the east of the trough, even in the presence of upwellingfavorable winds. Thus, the enhanced southward flow of the merged NIJ-separated EGC due to the negative wind stress curl, lowering the sea surface height in the trough, would be concomitate with a stronger northward-flowing NIIC. These ideas warrant further investigation, but are beyond the scope of the present study. 

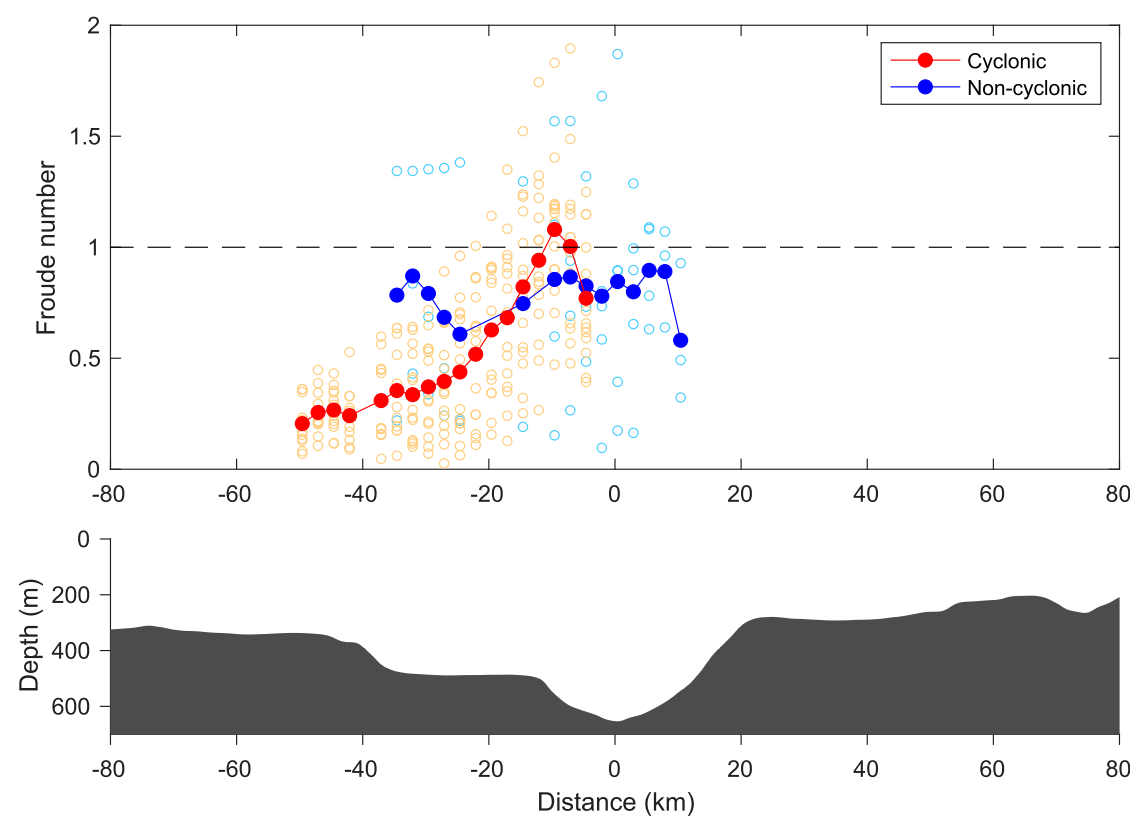

FIG. 9. Composite Froude number $G$ as a function of across-strait distance, for the cyclonic cases (red) and anticyclonic cases (blue). The individual values for the 22 occupations are open circles, and the mean values at each location are the filled circles. The critical value of $G=1$ is indicated by the dashed line. (bottom) The bathymetry.

\section{Dynamics in the trough}

\section{a. Hydraulic criticality}

Previous observations have shown that the density structure of the overflow water in Denmark Strait is consistent with that of hydraulic flow over a sill (e.g., Spall and Price 1998; Nikolopoulos et al. 2003). Using observations and a numerical model, Käse et al. (2003) diagnosed the hydraulic conditions in Denmark Strait using the local Froude number $\operatorname{Fr}=v / \sqrt{g^{\prime} D}$, where $v$ is the flow speed, $D$ is the vertical length scale, $g^{\prime}=g \Delta \rho / \rho$ is the reduced gravity, $g$ is the gravitational acceleration, and $\Delta \rho$ is the density difference across the interface. Käse et al. (2003) considered different parts of the domain and found that the flow upstream of the sill is subcritical $(\mathrm{Fr}<1)$, but, as the flow descends into the Irminger Basin and accelerates, it becomes supercritical $(\mathrm{Fr}>1)$. The transition location is roughly $100 \mathrm{~km}$ downstream of the sill. As shown by Pratt (1986), bottom friction can shift the transition point (critical section) from the sill to a location downstream. Such a downstream shift is evident in observations (Price and Baringer 1994), and in other models (Spall and Price 1998).

We investigated the Froude number using our 22 sections. In the scenario where the dense water flows beneath a motionless or slowly moving upper layer, the Froude number is the expression given above. In our case, especially for the cyclonic state, there is strong flow throughout the water column. As such, it is more appropriate to use the composite Froude number $G$ for two active layers (Armi 1986; Kösters 2004; Pratt 2008):

$$
G^{2}=\mathrm{Fr}_{1}^{2}+\mathrm{Fr}_{2}^{2}
$$

where $\operatorname{Fr}_{n}=v_{n} / \sqrt{g^{\prime} D_{n}}$ is the Froude number in the $n$th layer. The quantity $v_{n}$ is the vertically averaged advective speed in layer $n$, and $D_{n}$ is the layer thickness. A two-layer flow that is laterally uniform is considered supercritical when $G>1$ and subcritical when $G<1$. For flows with strong lateral variations in layer thickness and velocity, a local value of $G>1$ indicates that the flow is locally supercritical, but does not necessarily indicate that the flow as a whole is supercritical. In this case, locally generated disturbances will propagate downstream whereas disturbances that exist over the whole channel width may still propagate upstream (Pratt and Helfrich 2005). Thus, a flow may be supercritical at certain locations but also subcritical as a whole. We choose the $27.8 \mathrm{~kg} \mathrm{~m}^{-3}$ isopycnal as the interface between the two layers, since this is the top of the dense overflow water and also corresponds to the maximum in stratification (see also von Appen et al. 2017). (Using a slightly denser or lighter isopycnal did not change the results.)

For each occupation we calculated $G$ at the grid points across the section corresponding to the southward flow. Figure 9 shows the results, where we have distinguished between the cyclonic cases (red) and noncyclonic cases (blue). The individual realizations are plotted as open circles, and the means for the two cases at each cross-stream location are the solid circles. One sees that, for the cyclonic state, the mean $G$ exceeds 1 on the western flank of the trough where the merged NIJ-separated EGC is strongest (Fig. 6a). In all, 11 out of the 15 cyclonic realizations had $G>1$ in this part of the strait. By contrast, the mean $G$ for the noncyclonic state is less than 1 everywhere, although 4 out of the 7 realizations had a value of $G>1$ somewhere in the domain. As noted above, models and observations indicate that the overflow plume descending from 
Denmark Strait reaches hydraulic criticality approximately $100 \mathrm{~km}$ downstream of the sill. One is tempted to conclude from our measurements that localized hydraulic criticality also occurs intermittently at the sill itself, in the cyclonic configuration when the merged NIJ-separated EGC is intensified on the western flank of the trough. However, the presence of such a confined region where $G>1$ does not necessarily imply that strait-wide hydraulic control is occurring (Pratt and Helfrich 2005). Further work is required to shed light on this.

\section{b. Mixing and potential vorticity}

Although it remains unclear if the Denmark Strait sill can act as a location of strait-wide hydraulic control akin to what happens farther south, the strong flow at the Látrabjarg line, in conjunction with the weak stratification, result in another important aspect of supercritical flow-that of mixing. This can be assessed by considering the gradient Richardson number, defined as the ratio of the buoyancy frequency to the square of vertical shear in velocity,

$$
R i=-\frac{g}{\rho_{0}} \frac{\partial \rho}{\partial z}\left(\frac{\partial u}{\partial z}\right)^{-2},
$$

where $\rho$ is the local density, $\rho_{o}$ is the background density (section-wide average), and $u$ is the along-strait velocity. When $R i$ is less than the critical value of 0.25 the flow can be subject to Kelvin-Helmholtz instability, which leads to vertical mixing (in many studies the critical value is taken to be in the range 0.2-1.0; e.g., Galperin et al. 2007). To compute $R i$ we use a $\Delta z$ of $10 \mathrm{~m}$, although the results are not sensitive to this choice (we get comparable results for $\Delta z$ ranging from 5 to $20 \mathrm{~m}$ ). In Fig. 10 we show the vertical section of $R i$ (plotted using a logarithmic scale) for the July 2007 occupation, which is one of the sections where $G>1$ within the trough. This reveals a region of $R i<0.25$ [i.e., $\log (R i)<-1.4$, the red patch in Fig. 10a] along the steeply sloped density front separating the cold overflow water from the warm Irminger Water. In this case both the weak stratification and strong velocity shear contribute to the small value of $R i$. It is expected that strong vertical mixing would be occurring in this region.

To further investigate the nature and extent of mixing at the Látrabjarg line, we consider the potential vorticity dynamics of the flow using our 22 occupations. We did this by evaluating the Ertel potential vorticity (e.g., Spall and Pedlosky 2008; Lin et al. 2018),

$$
\Pi=-\frac{f}{\rho_{0}} \frac{\partial \rho}{\partial z}+\frac{1}{\rho_{0}} \frac{\partial u}{\partial y} \frac{\partial \rho}{\partial z}-\frac{1}{\rho_{0}} \frac{\partial u}{\partial z} \frac{\partial \rho}{\partial y},
$$

where the $y$ direction is cross-strait, positive toward Iceland. The Ertel potential vorticity (PV) has three components: 1 ) the planetary stretching PV term, dictated by the vertical stratification and Earth's rotation; 2) the vertical relative PV term, due to the combination of the lateral gradient of the horizontal velocity and vertical stratification; and 3) the horizontal relative PV term, due to the vertical gradient of horizontal velocity and lateral gradient of density. It is instructive to normalize the second and third terms by the planetary stretching term. For the vertical relative $\mathrm{PV}$, this gives
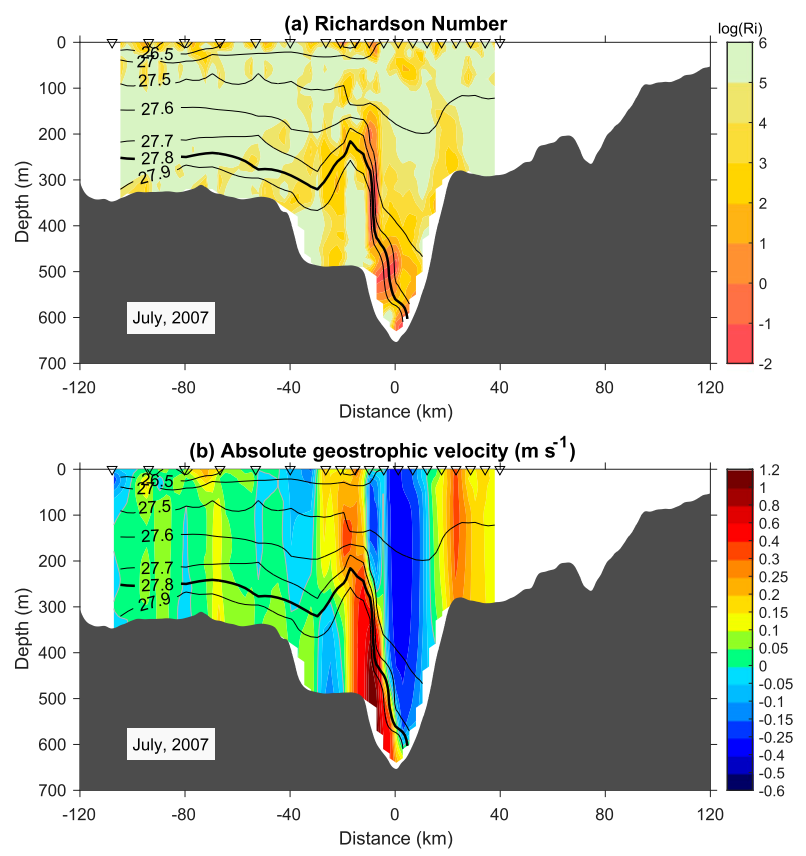

FIG. 10. Vertical sections of (a) the log of the gradient Richardson number $\left[\log (R i)\right.$, colors] and (b) absolute geostrophic velocity $\left(\mathrm{m} \mathrm{s}^{-1}\right.$, colors) overlain by potential density $\left(\mathrm{kg} \mathrm{m}^{-3}\right.$, contours) for the Látrabjarg occupation in July 2007. The highlighted isopycnal of $27.8 \mathrm{~kg} \mathrm{~m}^{-3}$ is the upper boundary of the overflow water. The inverted triangles indicate the station locations.

$$
R_{o}=-\frac{1}{f} \frac{\partial u}{\partial y}
$$

For the horizontal relative $\mathrm{PV}$, the ratio is

$$
R_{z}=-\frac{g \alpha}{f^{2} \rho_{0}} \frac{\partial \rho}{\partial y}
$$

where $\alpha$ is the isopycnal slope; to derive this, we used the thermal wind relation, $\partial u / \partial z=\left(g / f \rho_{0}\right)(\partial \rho / \partial y)$.

Using a representative length scale $L$ and velocity scale $U$, the first ratio [Eq. (4)] can be expressed as $R_{o}=U / f L$, which is the Rossby number. Taking $\Delta U$ as the change in velocity over the depth scale, the second ratio [Eq. (5)] can be expressed as $R_{z}=\Delta U / f L$, which has the form of a Rossby number associated with the depth variation in velocity; we refer to this as the shear Rossby number [it is also the negative of the inverse balanced Richardson number discussed in Thomas et al. (2013)]. Note that when the flow is barotropic $R_{z}$ will be small, even though $R_{o}$ could be large. When the flow is strongly baroclinic $R_{z}$ could be large.

Returning to the July 2007 occupation, we computed the total Ertel PV and its three components, where the latter two terms have been normalized to show $R_{o}$ and $R_{z}$ (Fig. 11). One sees that over most of the section the total PV is qualitatively similar to the stretching term, particularly in the upper layer. However, in the trough the other two terms are significant. The large Rossby number (up to 1.5 ) changes sign across the merged NIJ-separated EGC, indicating that this flow is highly 

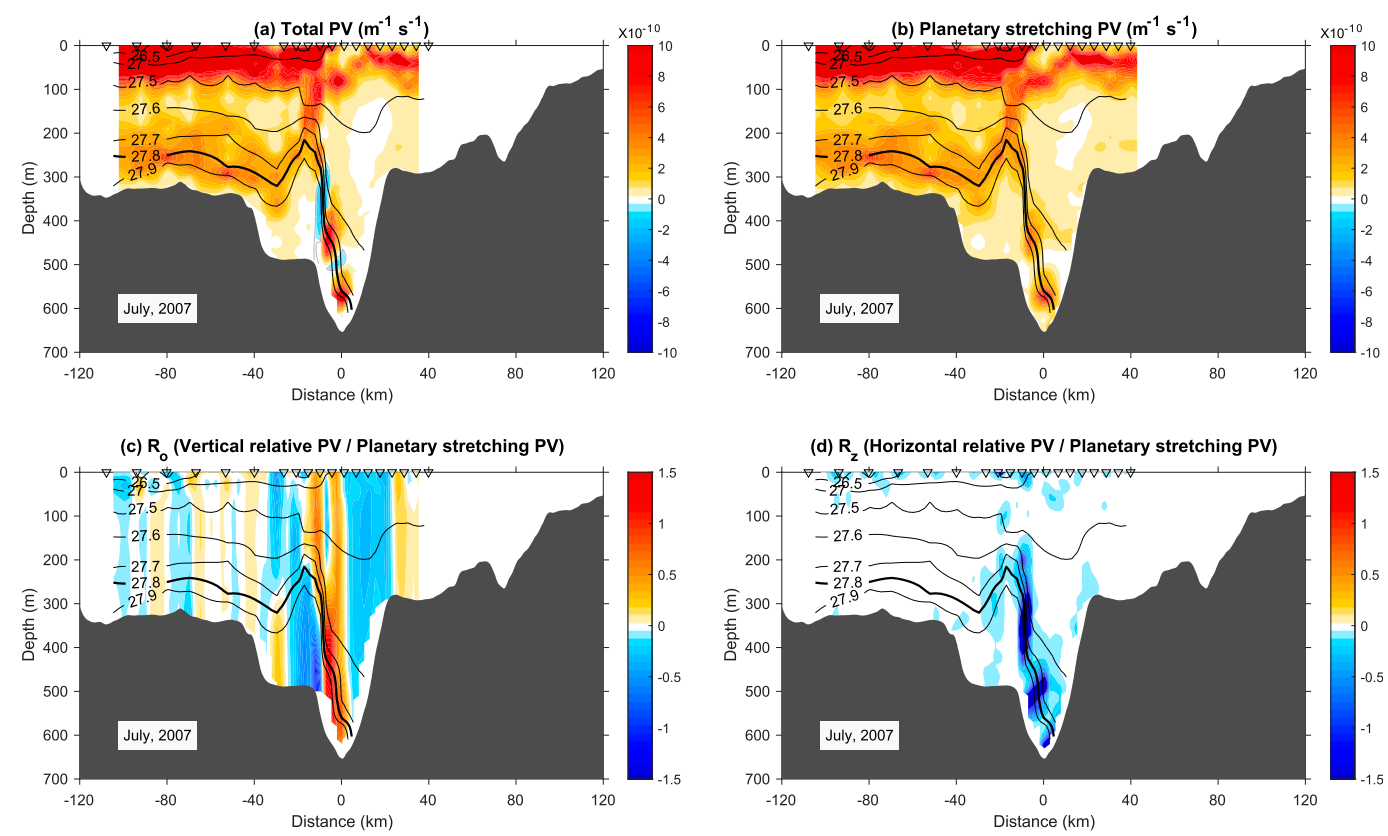

FIG. 11. Vertical sections of the components of the Ertel potential vorticity (colors) for the July 2007 Látrabjarg occupation, overlain by potential density $\left(\mathrm{kg} \mathrm{m}^{-3}\right.$, contours). (a) Total potential vorticity $\left(\times 10^{-10} \mathrm{~m}^{-1} \mathrm{~s}^{-1}\right)$. (b) Planetary stretching PV $\left(\times 10^{-10} \mathrm{~m}^{-1} \mathrm{~s}^{-1}\right)$. (c) The ratio of vertical relative PV to planetary stretching PV $\left(R_{o}\right)$. (d) The ratio of horizontal relative PV to planetary stretching PV $\left(R_{z}\right)$. The highlighted isopycnal of $27.8 \mathrm{~kg} \mathrm{~m}^{-3}$ is the upper boundary of the overflow water. The inverted triangles indicate the station locations.

nonlinear, and may be barotropically unstable (Pickart et al. 2005). Furthermore, the lateral gradient of the total PV changes sign with depth in the trough (Fig. 11a), which is a necessary condition for baroclinic instability. This is in line with the model results of Spall et al. (2019), who identified that both the merged NIJ-separated EGC and NIIC are baroclinically unstable. This instability acts to weaken the hydrographic front that is maintained by the convergence of the large-scale mean flow.

Note also in Fig. 11 that, due to the steeply sloped isopycnals of the hydrographic front (and corresponding strong velocity shear via thermal wind), the shear Rossby number is less than -1 , i.e., the same order as the Rossby number. This results in regions of negative total PV; in particular, note the correspondence between the strong horizontal relative PV in Fig. 11d and negative $\Pi$ in Fig. 11a. The condition of negative total PV can lead to symmetric instability (Haine and Marshall 1998; D’Asaro et al. 2011), a fast-growing instability that generally occurs on the order of a few hours (Brearley et al. 2012). At finite amplitude this results in intense, rapid diapycnal mixing (Haine and Marshall 1998). We now explore further the signature of symmetric instability in our data.

\section{c. Symmetric instability}

Based on the July 2007 occupation, we seek to elucidate the relationship between the horizontal relative PV, or more specifically $R_{z}$, and the occurrence of negative PV. Using all the grid points of the 22 realizations, we regressed $R_{z}$ against $\Pi$ (Fig. 12). This shows that when $R_{z}<-1,73 \%$ of the time this corresponds to negative PV (if the threshold is strengthened to -1.5 , the percentage of negative PV is $93 \%$ ). For the remaining $27 \%$ of the data points, the strong positive vertical relative PV on the eastern side of the merged NIJ-separated EGC overcomes the horizontal relative PV, such that the total $\mathrm{PV}$ remains positive. This is seen in Fig. 12, where the value of $R_{o}$ for each data point is indicated using color. The points in question generally have $0.5<R_{o}<1.5$. Alternatively, the color in Fig. 12 reveals that when negative PV does not correspond to $R_{z}<-1$ this is due to large negative $R_{o}$ on the western side of the merged NIJ-separated EGC (dark blue symbols in Fig. 12). We thus conclude that, outside of extreme instances of large vertical relative PV (of either sign), it is generally the case that when the shear Rossby number is less than -1 , the total PV is negative-which will result in symmetric instability. This threshold is consistent with the classification of symmetric instability in Thomas et al. (2013), who also considered the contribution of the vertical relative PV.

Part of our rationale for casting the symmetric instability condition in terms of $R_{z}$ is that this ratio does not depend on the velocity of the flow, but only on the density structure [see Eq. (5)]. As such, we can extend the application of the proxy to the complete set of historical hydrographic Látrabjarg sections (we exclude 9 short sections that did not cross the trough). We find that $R_{z}<-1$ in 60 of the 112 sections, i.e., over $50 \%$ of the time (for the more restrictive criterion of $R_{z}<-1.5$ it is $42 \%$ ). This suggests that symmetric instability occurs quite frequently in Denmark Strait. Interestingly, the presence of symmetric instability does not seem to be tied to the cyclonic or noncyclonic velocity states, or to the presence of boluses versus pulses. 


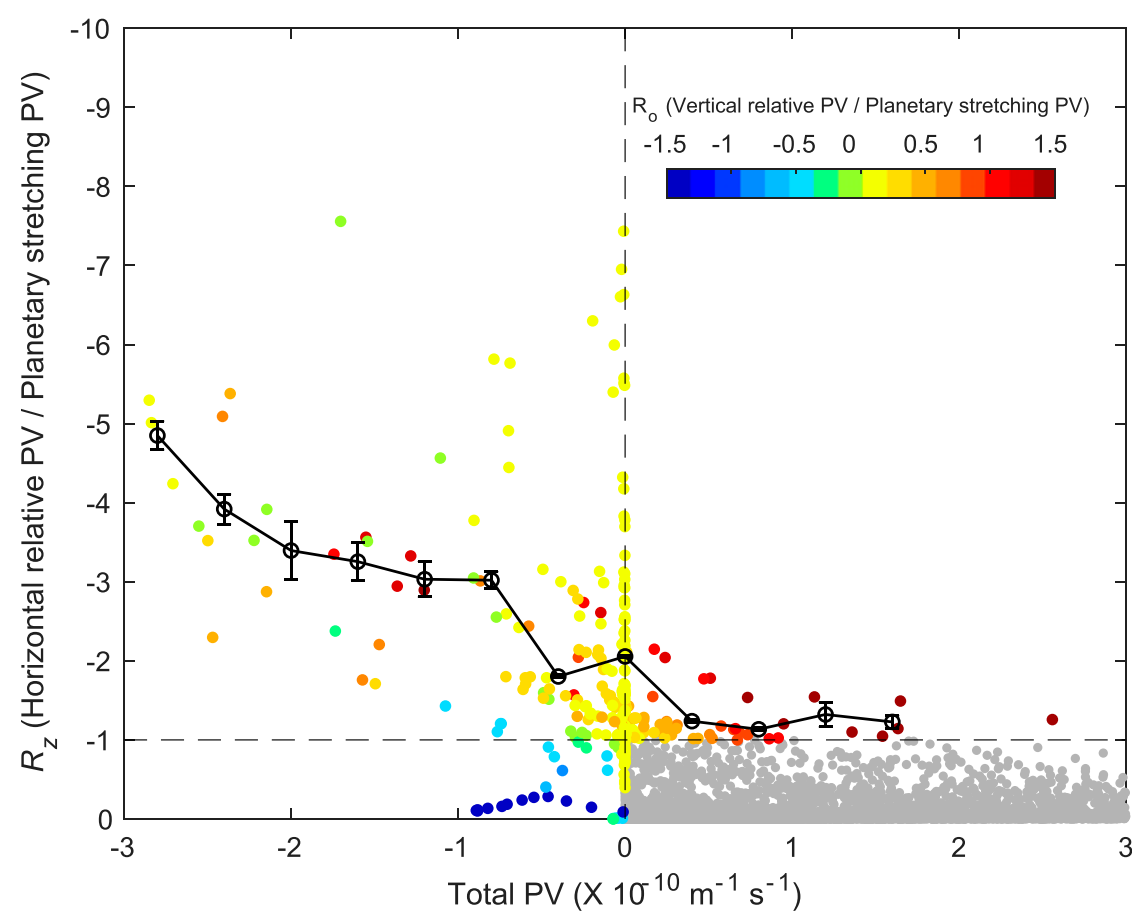

FIG. 12. Scatterplot of the shear Rossby number $R_{z}$ vs total the potential vorticity $\Pi$, using the 22 Látrabjarg sections with velocity. The data points are colored by the value of the Rossby number $R_{o}$ except for cases when $R_{z}>-1$ and $\Pi>0$, which are shaded gray. The black line with open circles is the average value of $R_{z}$ when it is less than -1 , for each PV bin (bin size of $0.4 \times 10^{-10} \mathrm{~m}^{-1} \mathrm{~s}^{-1}$ ). The standard errors are included.

To determine where in the water column the conditions for symmetric instability occur, we tabulated the occurrences of $R_{z}<-1$ for all of the sections (Fig. 13). This reveals that the instability occurs mainly in the trough, with a few instances near the surface on the Iceland shelf and near the bottom in the vicinity of the Greenland shelf break. However, the majority of cases are clustered into two areas: a deeper region near the western side of the trough and a shallower region closer to the eastern side of the trough. To shed light on the underlying reasons for this pattern, we constructed a composite hydrographic section for all of the occurrences in the deeper region, then did the same for the shallower region. These are shown in Fig. 14. For the shallower occurrences there is a large amount of cold overflow water filling the trough, while for the deeper occurrences there is only a thin layer of this water banked on the western side of the trough. These two states correspond nearly identically with the hydrographic patterns of boluses and pulses, respectively (von Appen et al. 2017). Note that in both cases the instability takes place in the steep frontal zone, where the horizontal relative $\mathrm{PV}$ is strongly negative. This result suggests that strong vertical mixing occurs at the top of the overflow layer, regardless of whether there is a large or small amount of dense water present. The implication is that, even though strait-wide hydraulic control may not be achieved until downstream of Denmark Strait, the mixing/entrainment process that modifies the overflow water begins at the sill (also see North et al. 2018).

\section{Summary and discussion}

In this study we have used 22 occupations of the Látrabjarg line from 1993 to 2018, together with reanalysis wind fields and satellite absolute dynamic topography data, to investigate the kinematic structure and dynamics of the Denmark Strait Overflow Water. While the Látrabjarg section has been occupied over 100 times through the years, the unique aspect of the subset considered here is that it includes vesselmounted/lowered ADCP velocity data that were used to construct vertical sections of absolute geostrophic velocity. The mean velocity section reveals the presence of the shelfbreak EGC in the vicinity of the Greenland shelf edge, the merged NIJ-separated EGC banked against the western side

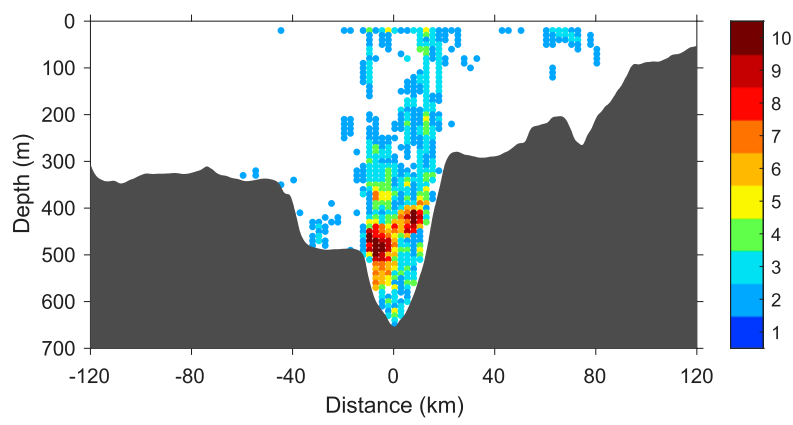

FIG. 13. Occurrence of symmetric instability for the 122 hydrographic Látrabjarg sections, colored by number of realizations. 
(a) Potential temperature

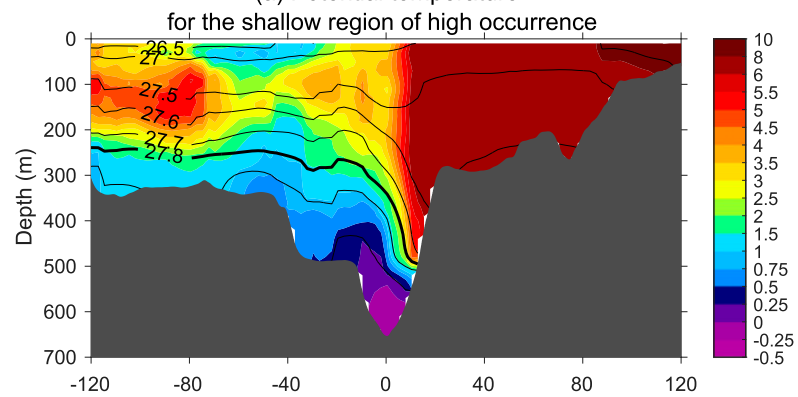

(b) Potential temperature

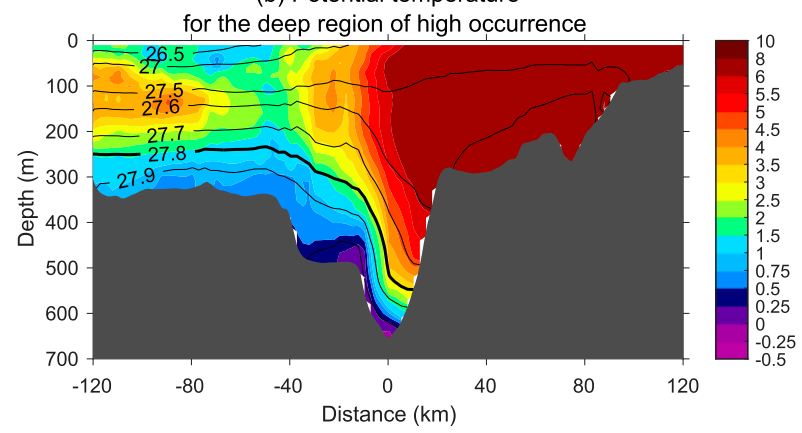

FIG. 14. Composite average sections of potential temperature $\left({ }^{\circ} \mathrm{C}\right.$, colors) overlain by potential density ( $\mathrm{kg} \mathrm{m}^{-3}$, contours) corresponding to the (a) shallow and (b) deep regions of high occurrence of symmetric instability in Fig. 13. The highlighted isopycnal of $27.8 \mathrm{~kg} \mathrm{~m}^{-3}$ is the upper boundary of the overflow water.

of the deep trough, and the northward-flowing NIIC near the Iceland shelf break.

The mean transport of the overflow water (denser than $27.8 \mathrm{~kg} \mathrm{~m}^{-3}$ ) is $3.54 \pm 0.29 \mathrm{~Sv}$, which includes an extrapolated estimate of the unresolved component on the Greenland shelf $(0.54 \mathrm{~Sv})$. This is close to previously published estimates of the mean overflow transport (Harden et al. 2016; Jochumsen et al. 2017). We partitioned the transport in terms of water masses and current components. For the former we used a hydrographic end-member analysis to distinguish Atlantic-origin Overflow Water (AtOW) from Arctic-origin Overflow Water (ArOW). Assuming that the unresolved overflow transport on the Greenland shelf is AtOW, this gives $1.72 \pm 0.15 \mathrm{~Sv}$ for ArOW and $1.49 \pm 0.10 \mathrm{~Sv}$ for AtOW, indicating that the mean transports of the two types of overflow water are comparable in Denmark Strait. For the currents, we distinguished the shelfbreak EGC and the merged NIJ-separated EGC using a geographical boundary, and assumed that the unresolved overflow water on the Greenland shelf emanated from the shelfbreak EGC upstream of the strait. This gives $1.39 \pm 0.14 \mathrm{~Sv}$ for the shelfbreak EGC and $2.15 \pm 0.15 \mathrm{~Sv}$ for the merged flow, which is in line with similar partitioning done by Harden et al. (2016) upstream in the Blosseville Basin. Notably, both currents transport both types of overflow water, implying a significant degree of exchange between the branches as they converge in Denmark Strait.

With regard to temporal variability, there were two dominant configurations of the flow which we refer to as the cyclonic state and the noncyclonic state. The former is characterized by a strong southward flow of the merged NIJ-separated EGC adjacent to a strong northward flow of the NIIC. This structure was present in 15 of the 22 occupations. In this state the NIIC is located farther to the west and occupies part of the trough. The remaining 7 sections corresponded to weaker southward and northward flows, with the NIIC shifted eastward and the entire trough associated with the merged NIJ-separated EGC. Using the reanalysis wind data, it was demonstrated that the cyclonic state corresponds to negative wind stress curl north of the strait in the Blosseville Basin and strong northeasterly winds within the strait. The former is conducive for an enhanced merged flow as demonstrated previously (Våge et al. 2013). Using the satellite surface geostrophic velocity data, we showed that the NIIC becomes stronger and shifts closer to the shelf break under northeasterly winds, although the physical mechanism for this remains unresolved.

The hydraulic criticality of the flow was assessed using a composite Froude number that can account for two moving layers - the overflow layer and the lighter water above. This revealed that roughly two thirds of the cyclonic realizations had regions of supercritical flow in the trough, and this condition was present in the mean for the strongest flow in the merged NIJ-separated EGC. This suggests that hydraulic control could be occurring intermittently during the cyclonic state. However, the presence of such a confined region of large Froude number does not necessarily imply that straitwide hydraulic control is occurring (Pratt and Helfrich 2005).

A potential vorticity (PV) analysis of the 22 occupations indicated that the flow through Denmark Strait is subject to symmetric instability. This occurs when the total PV is negative, which tends to happen when the horizontal relative PV becomes strongly negative. We determined that the shear Rossby number $\left(R_{z}\right)$ is a good proxy for determining when symmetric instability is active. In particular, when $R_{z}$ is less than -1 , the total PV is typically negative. This proxy, which does not rely on the flow speed but only the density structure, was then applied to the full set of 122 Látrabjarg occupations. This revealed that symmetric instability tends to occur at the top of the overflow layer, regardless of whether there is a large or small amount of dense water in the strait. Symmetric instability is a fast-growing instability that generally reaches finite amplitude in a matter of hours, leading to intense vertical mixing. This implies that, even though hydraulic criticality may not be achieved until downstream of the strait, the mixing/entrainment process that modifies the overflow water begins at the sill.

Previous work has implied that the dominant mesoscale variability in Denmark Strait is due to baroclinic instability of the hydrographic front that separates the overflow water from the subtropical-origin water in the NIIC (Spall et al. 2019). The resulting meanders of the front propagate equatorward through the strait and are associated with the wellknown boluses and pulses of overflow water (Mastropole et al. 2017; von Appen et al. 2017). In particular, meander crests are associated with boluses, which correspond to a thick layer of overflow water, whereas meander troughs coincide with pulses, which are characterized by a thin layer of overflow water. 
The results presented here suggest that the dominant variation in alongstream velocity at the sill is wind-driven, rather than being associated with the amount of overflow water present. There are several factors that may help explain this apparent discrepancy.

The numerical model results of Almansi et al. (2017) show that, relative to the background state, the biggest difference in the alongstream velocity signature of the boluses and pulses is the bottom intensification associated with the latter. While we do not have enough realizations of the Látrabjarg section with velocity to determine a background state, our composite of pulse realizations shows significantly more bottom intensification in the trough versus the composite of bolus realizations, in line with Almansi et al.'s (2017) results. Another thing to keep in mind is that the mooring analysis of von Appen et al. (2017) showed that the most conspicuous difference between the passage of boluses versus pulses pertains to the crossstream velocity signal (cyclonic for boluses, anticyclonic for pulses), which we are unable to assess. Both features were associated with an enhancement of the alongstream velocity in the overflow layer. The maximum flow in von Appen et al.'s (2017) bolus composite exceeded $0.40 \mathrm{~m} \mathrm{~s}^{-1}$, while that for their pulse composite exceeded $0.60 \mathrm{~m} \mathrm{~s}^{-1}$. In our composite vertical sections, the mean near-bottom flow of the pulses is only slightly larger than for the boluses $\left(0.30 \mathrm{vs} 0.24 \mathrm{~m} \mathrm{~s}^{-1}\right)$, but it must be kept in mind that the mooring composites were based on vastly more data. In any event, both the shear and the magnitude of the alongstream flow-together with the strong hydrographic signals-suggest that we indeed detect these mesoscale features.

A final consideration regarding the velocity variability seen in our dataset is the short time scale associated with the passage of the boluses and pulses. The mooring composites of von Appen et al. (2017) indicate that, for both types of features, the strongest signals in alongstream velocity persist for approximately $12 \mathrm{~h}$. Typical occupations of the Látrabjarg line take a day or more to complete. This means that the timing has to be perfect for a shipboard transect to capture the peak alongstream velocity signature of one these mesoscale features in the trough. On the other hand, the wind-driven flow variability takes place over longer time scales. The ERA5 data indicate that the autocorrelation time for the along-strait winds is $73 \mathrm{~h}$. Therefore, it is more likely that a given transect will be under the influence of a single wind state. As the collection of Látrabjarg occupations with velocity continues to increase over time, we will be better positioned to elucidate the impacts of external versus internal forcing of the overflow water.

Acknowledgments. An inordinate amount of effort was required to obtain, processes, and quality-control the data used in this study. The authors are thankful for the efforts of the many individuals, both at sea and ashore, that made the analysis possible. We are also indebted to M. Spall, T. Haine, and S. Tan for valuable discussions and insights. Funding for the study was provided by National Science Foundation (NSF) Grants OCE-1259618, OCE-1756361, and OCE-1558742. The German research cruises were financially supported through various EU Projects (e.g. THOR, NACLIM) and national projects (most recently TRR 181 "Energy Transfer in Atmosphere and Ocean" funded by the German Research Foundation and RACE II "Regional Atlantic Circulation and Global Change" funded by the German Federal Ministry for Education and Research). GWKM acknowledges the support of the Natural Sciences and Engineering Research Council of Canada. LP was supported by NSF Grant OCE-1657870.

\section{REFERENCES}

Almansi, M., T. W. Haine, R. S. Pickart, M. G. Magaldi, R. Gelderloos, and D. Mastropole, 2017: High-frequency variability in the circulation and hydrography of the Denmark Strait overflow from a high-resolution numerical model. J. Phys. Oceanogr., 47, 2999-3013, https://doi.org/10.1175/ JPO-D-17-0129.1.

_, T. Haine, R. Gelderloos, and R. Pickart, 2020: Evolution of Denmark Strait overflow cyclones and their relationship to overflow surges. Geophys. Res. Lett., 47, e2019GL086759, https://doi.org/10.1029/2019GL086759.

Armi, L., 1986: The hydraulics of two flowing layers with different densities. J. Fluid Mech., 163, 27-58, https://doi.org/10.1017/ S0022112086002197.

Brearley, J. A., R. S. Pickart, H. Valdimarsson, S. Jonsson, R. W. Schmitt, and T. W. Haine, 2012: The East Greenland boundary current system south of Denmark Strait. Deep-Sea Res. I, 63, 1-19, https://doi.org/10.1016/j.dsr.2012.01.001.

Bruce, J., 1995: Eddies southwest of the Denmark Strait. Deep-Sea Res. I, 42, 13-29, https://doi.org/10.1016/0967-0637(94)00040-Y.

Casanova-Masjoan, M., and Coauthors, 2020: Along-stream, seasonal and interannual variability of the North Icelandic Irminger Current and East Icelandic Current around Iceland. J. Geophys. Res. Ocean, 125, e2020JC016283, https://doi.org/ 10.1029/2020JC016283.

D'Asaro, E., C. Lee, L. Rainville, R. Harcourt, and L. Thomas, 2011: Enhanced turbulence and energy dissipation at ocean fronts. Science, 332, 318-322, https://doi.org/10.1126/science.1201515.

de Steur, L., E. Hansen, R. Gerdes, M. Karcher, E. Fahrbach, and J. Holfort, 2009: Freshwater fluxes in the East Greenland Current: A decade of observations. Geophys. Res. Lett., 36, L23611, https://doi.org/10.1029/2009GL041278.

Dickson, R. R., and J. Brown, 1994: The production of North Atlantic deep water: Sources, rates, and pathways. J. Geophys. Res., 99, 12 319-12 341, https://doi.org/10.1029/94JC00530.

Galperin, B., S. Sukoriansky, and P. S. Anderson, 2007: On the critical Richardson number in stably stratified turbulence. Atmos. Sci. Lett., 8, 65-69, https://doi.org/10.1002/asl.153.

Girton, J. B., and T. B. Sanford, 2003: Descent and modification of the overflow plume in the Denmark Strait. J. Phys. Oceanogr., 33, 1351-1364, https://doi.org/10.1175/1520-0485(2003)033<1351: DAMOTO $>2.0 . \mathrm{CO} ; 2$.

Haine, T. W., and J. Marshall, 1998: Gravitational, symmetric, and baroclinic instability of the ocean mixed layer. J. Phys. Oceanogr., 28, 634-658, https://doi.org/10.1175/1520-0485(1998)028<0634: $\mathrm{GSABIO}>2.0 . \mathrm{CO} ; 2$.

Harden, B. E., and Coauthors, 2016: Upstream sources of the Denmark Strait overflow: Observations from a high-resolution mooring array. Deep-Sea Res. I, 112, 94-112, https://doi.org/ 10.1016/j.dsr.2016.02.007.

Håvik, L., R. S. Pickart, K. Våge, D. Torres, A. M. Thurnherr, A. Beszczynska-Möller, W. Walczowski, and W. J. von Appen, 2017a: Evolution of the east Greenland current from Fram Strait to Denmark strait: Synoptic measurements from summer 
2012. J. Geophys. Res. Oceans, 122, 1974-1994, https://doi.org/ 10.1002/2016JC012228.

—, K. Våge, R. Pickart, B. Harden, W.-J. Appen, S. Jónsson, and S. Østerhus, 2017b: Structure and variability of the shelfbreak East Greenland current north of Denmark Strait. J. Phys. Oceanogr., 47, 2631-2646, https://doi.org/10.1175/JPO-D-17-0062.1.

Holte, J., and F. Straneo, 2017: Seasonal overturning of the Labrador Sea as observed by Argo floats. J. Phys. Oceanogr., 47, 2531-2543, https://doi.org/10.1175/JPO-D-17-0051.1.

Høyer, J. L., and D. Quadfasel, 2001: Detection of deep overflows with satellite altimetry. Geophys. Res. Lett., 28, 1611-1614, https://doi.org/10.1029/2000GL012549.

Huang, J., R. S. Pickart, H. Valdimarsson, P. Lin, M. A. Spall, and F. Xu, 2019: Structure and variability of the North Icelandic Jet from two years of mooring data. J. Geophys. Res. Oceans, 124, 3987-4002, https://doi.org/10.1029/2019JC015134.

,-- , R. X. Huang, P. Lin, A. Brakstad, and F. Xu, 2020: Sources and upstream pathways of the densest overflow in the Nordic Seas. Nat. Commun., https://doi.org/10.1038/s41467020-19050-y, in press.

Jochumsen, K., D. Quadfasel, H. Valdimarsson, and S. Jónsson, 2012: Variability of the Denmark Strait overflow: Moored time series from 1996-2011. J. Geophys. Res., 117, C12003, https://doi.org/10.1029/2012JC008244.

—, M. Moritz, N. Nunes, D. Quadfasel, K. M. Larsen, B. Hansen, H. Valdimarsson, and S. Jonsson, 2017: Revised transport estimates of the Denmark Strait overflow. J. Geophys. Res. Oceans, 122, 3434-3450, https://doi.org/10.1002/2017JC012803.

Käse, R. H., J. Girton, and T. Sanford, 2003: Structure and variability of the Denmark Strait overflow: Model and observations. J. Geophys. Res., 108, 3181, https://doi.org/10.1029/2002JC001548.

Kösters, F., 2004: Denmark Strait overflow: Comparing model results and hydraulic transport estimates. J. Geophys. Res., 109, C10011, https://doi.org/10.1029/2004JC002297.

Lin, P., R. S. Pickart, D. J. Torres, and A. Pacini, 2018: Evolution of the freshwater coastal current at the southern tip of Greenland. J. Phys. Oceanogr., 48, 2127-2140, https://doi.org/10.1175/JPO-D18-0035.1.

Logemann, K., J. Ólafsson, Á. Snorrason, H. Valdimarsson, and G. Marteinsdóttir, 2013: The circulation of Icelandic waters-A modelling study. Ocean Sci., 9, 931-955, https://doi.org/10.5194/ os-9-931-2013.

Lozier, M., and Coauthors, 2019: A sea change in our view of overturning in the subpolar North Atlantic. Science, 363, 516 521, https://doi.org/10.1126/science.aau6592.

Macrander, A., 2004: Variability and processes of the Denmark Strait overflow. Ph.D. dissertation, Christian-Albrechts-Universität, 183 pp.

Mastropole, D., R. S. Pickart, H. Valdimarsson, K. Våge, K. Jochumsen, and J. Girton, 2017: On the hydrography of Denmark Strait. J. Geophys. Res. Oceans, 122, 306-321, https://doi.org/10.1002/ 2016JC012007.

Mauritzen, C., 1996: Production of dense overflow waters feeding the North Atlantic across the Greenland-Scotland Ridge. Part 1: Evidence for a revised circulation scheme. Deep-Sea Res. I, 43, 769-806, https://doi.org/10.1016/0967-0637(96)00037-4.

Moritz, M., K. Jochumsen, R. P. North, D. Quadfasel, and H. Valdimarsson, 2019: Mesoscale eddies observed at the Denmark Strait sill. J. Geophys. Res. Oceans, 124, 7947-7961, https://doi.org/10.1029/2019JC015273.

Nikolopoulos, A., K. Borenäs, R. Hietala, and P. Lundberg, 2003: Hydraulic estimates of Denmark Strait overflow. J. Geophys. Res., 108, 3095, https://doi.org/10.1029/2001JC001283.
R. S. Pickart, P. S. Fratantoni, K. Shimada, D. J. Torres, and E. P. Jones, 2009: The western Arctic boundary current at $152^{\circ} \mathrm{W}$ : Structure, variability, and transport. Deep-Sea Res. II, 56, 1164-1181, https://doi.org/10.1016/j.dsr2.2008.10.014.

North, R. P., K. Jochumsen, and M. Moritz, 2018: Entrainment and energy transfer variability along the descending path of the Denmark Strait overflow plume.J. Geophys. Res. Oceans, 123, 2795-2807, https://doi.org/10.1002/2018JC013821.

Østerhus, S., T. Sherwin, D. Quadfasel, and B. Hansen, 2008: The overflow transport east of Iceland. Arctic-Subarctic Ocean Fluxes, Springer, 427-441.

Pickart, R. S., and M. A. Spall, 2007: Impact of Labrador Sea convection on the north Atlantic meridional overturning circulation. J. Phys. Oceanogr., 37, 2207-2227, https://doi.org/ 10.1175/JPO3178.1.

— D. J. Torres, and P. S. Fratantoni, 2005: The east Greenland spill jet. J. Phys. Oceanogr., 35, 1037-1053, https://doi.org/ 10.1175/JPO2734.1.

— , G. Moore, C. Mao, F. Bahr, C. Nobre, and T. J. Weingartner, 2016: Circulation of winter water on the Chukchi shelf in early summer. Deep-Sea Res. II, 130, 56-75, https://doi.org/10.1016/ j.dsr2.2016.05.001.

_ , and Coauthors, 2017: The North Icelandic jet and its relationship to the north Icelandic Irminger Current. J. Mar. Res., 75, 605-639, https://doi.org/10.1357/002224017822109505.

Pratt, L. J., 1986: Hydraulic control of sill flow with bottom friction. J. Phys. Oceanogr., 16, 1970-1980, https://doi.org/10.1175/ 1520-0485(1986)016<1970:HCOSFW >2.0.CO;2.

, 2008: Critical conditions and composite Froude numbers for layered flow with transverse variations in velocity. J. Fluid Mech., 605, 281-291, https://doi.org/10.1017/S002211200800150X.

__ , and K. Helfrich, 2005: Generalized conditions for hydraulic criticality of oceanic overflows. J. Phys. Oceanogr., 35, 17821800, https://doi.org/10.1175/JPO2788.1.

Price, J. F., and M. O. N. Baringer, 1994: Outflows and deep water production by marginal seas. Prog. Oceanogr., 33, 161-200, https://doi.org/10.1016/0079-6611(94)90027-2.

Rudels, B., P. Eriksson, H. Grönvall, R. Hietala, and J. Launiainen, 1999: Hydrographic observations in Denmark Strait in fall 1997, and their implications for the entrainment into the overflow plume. Geophys. Res. Lett., 26, 1325-1328, https:// doi.org/10.1029/1999GL900212.

— , G. Björk, J. Nilsson, P. Winsor, I. Lake, and C. Nohr, 2005: The interaction between waters from the Arctic Ocean and the Nordic seas north of Fram Strait and along the East Greenland Current: Results from the Arctic Ocean-02 Oden expedition. J. Mar. Syst., 55, 1-30, https://doi.org/10.1016/ j.jmarsys.2004.06.008.

Semper, S., K. Våge, R. S. Pickart, H. Valdimarsson, D. J. Torres, and S. Jónsson, 2019: The emergence of the North Icelandic Jet and its evolution from northeast Iceland to Denmark Strait. J. Phys. Oceanogr., 49, 2499-2521, https://doi.org/10.1175/JPO-D19-0088.1.

Smith, P. C., 1976: Baroclinic instability in the Denmark Strait overflow. J. Phys. Oceanogr., 6, 355-371, https://doi.org/10.1175/ 1520-0485(1976)006<0355:BIITDS > 2.0.CO;2.

Spall, M. A., and J. F. Price, 1998: Mesoscale variability in Denmark Strait: The PV outflow hypothesis. J. Phys. Oceanogr., 28, 1598-1623, https://doi.org/10.1175/1520-0485(1998)028<1598: MVIDST $>2.0 . C O ; 2$.

, and J. Pedlosky, 2008: Lateral coupling in baroclinically unstable flows. J. Phys. Oceanogr., 38, 1267-1277, https://doi.org/ 10.1175/2007JPO3906.1. 
,-- , and C. Cenedese, 2017: Circulation induced by isolated dense water formation over closed topographic contours. J. Phys. Oceanogr., 47, 2251-2265, https://doi.org/10.1175/ JPO-D-17-0042.1.

—, R. S. Pickart, P. Lin, W.-J. Appen, D. Mastropole, H. Valdimarsson, T. W. Haine, and M. Almansi, 2019: Frontogenesis and variability in Denmark Strait and its influence on overflow water. J. Phys. Oceanogr., 49, 1889-1904, https://doi.org/10.1175/JPO-D-19-0053.1.

Thomas, L. N., J. R. Taylor, R. Ferrari, and T. M. Joyce, 2013: Symmetric instability in the Gulf stream. Deep-Sea Res. II, 91, 96-110, https://doi.org/10.1016/j.dsr2.2013.02.025.

Våge, K., R. S. Pickart, M. A. Spall, H. Valdimarsson, S. Jónsson, D. J. Torres, S. Østerhus, and T. Eldevik, 2011: Significant role of the North Icelandic Jet in the formation of Denmark Strait overflow water. Nat. Geosci., 4, 723-727, https:// doi.org/10.1038/ngeo1234.

,,,--- G. Moore, H. Valdimarsson, D. J. Torres, S. Y. Erofeeva, and J. E. Ø. Nilsen, 2013: Revised circulation scheme north of the Denmark Strait. Deep-Sea Res. I, 79, 20-39, https://doi.org/10.1016/j.dsr.2013.05.007.

— , G. W. K. Moore, S. Jónsson, and H. Valdimarsson, 2015: Water mass transformation in the Iceland Sea. Deep-Sea Res. I, 101, 98-109, https://doi.org/10.1016/j.dsr.2015.04.001.

von Appen, W.-J., D. Mastropole, R. S. Pickart, H. Valdimarsson, S. Jónsson, and J. B. Girton, 2017: On the nature of the mesoscale variability in Denmark Strait. J. Phys. Oceanogr., 47, 567-582, https://doi.org/10.1175/JPO-D-16-0127.1. 